\title{
Fabuła zagadki. O Błędnych gwiazdach Wielkiej Niedźwiedzicy Luchina Viscontiego
}

\begin{abstract}
Igielska Anna, Fabuła zagadki. O Błędnych gwiazdach Wielkiej Niedźwiedzicy Luchina Viscontiego [The Plot of a Riddle. On Luchino Visconti's Vaghe stelle dell'Orsa]. „Przestrzenie Teorii" 32. Poznań 2019, Adam Mickiewicz University Press, pp. 45-75. ISSN 1644-6763. DOI 10.14746/pt.2019.32.2.

The article (of an analytical and interpretative nature) is devoted to the literary background of Luchino Visconti's Vaghe stelle dell'Orsa (1965). The author studies in detail the links to three works, which form, as she claims, the primary points of literary references. What the article discusses, apart from the myth of Electra and Gabriele D'Annunzio's novel Forse che si, forse che no (1910), are Richard Wagner's music drama Die Walküre (1870) - absent so far in the Viscontian literature concerning the said movie - and Thomas Mann's novella Wälsungenblut (1905/1958), which argues with Wagner's work in a parodistic manner. By demonstrating how Visconti (1) transposes the literary allusions, (2) combines them into an overall structure, and (3) uses them on the plot level to encode the topic of brother- sister incest, the author comes to the conclusion that what we have here is a story in the form of a riddle, which Visconti dubbed for his own use a "crime movie unlike any other". That riddle appears as a settlement with a romantic myth of love and carries on the poetics of philosophical ambivalence, so proper to Visconti.
\end{abstract}

KEYWORDS: Visconti, Luchino (1906-1976), Vaghe stelle dell'Orsa (1965), Forse che si, forse che no (1910), Die Walküre (1870), Wälsungenblut (1905/1958)

Grecki dramat starożytny (Ofiarnice Ajschylosa, Elektra - Sofoklesa i Eurypidesa), dramat elżbietański (Szkoda, że jest ladacznica Johna Forda [1633]), literatura włoskiego romantyzmu (Giacomo Leopardi) i dekadentyzmu (Może tak, może nie Gabriele’a D’Annunzia [1910]), literatura współczesna (Żałoba przystoi Elektrze Eugene’a O’Neille’a [1931], Ogród Finzi-Continich Giorgia Bassaniego) - wykaz inspiracji książkowych Luchina Viscontiego towarzyszących powstawaniu filmu Btędne gwiazdy Wielkiej Niedźwiedzicy (1965) jest bogaty ${ }^{1}$ i nieraz już, także na gruncie polskim, zwracano uwagę na sposób dialogowania dzieła z wielkimi tematami i mitami trwale obecnymi w literaturze Zachodu. Największy brak w badaniach tych relacji dotyczy hierarchizacji utworów, do których implicite lub explicite odwołuje się reżyser. Moim zamierzeniem nie jest dokładne ustalenie udziału poszczególnych dzieł cytowanych, lecz wskazanie tych, które składają się

${ }^{1}$ Zob. L. Micciché, Luchino Visconti. Un profilo critico, Venezia $2002^{2}$, s. $50-51$. 
na warstwę prymarnych odniesień literackich i wyciagnięcie wniosków co do sposobu pracy Viscontiego. Przedmiotem analizy jest film na pewno nie mistrzowski, ale wciąż dyskutowany i badany od strony źródłowej, a przede wszystkim wreszcie dostępny w swoim pierwotnym kształcie artystycznym dzięki zrealizowanemu w 2003 roku japońskiemu wydaniu płytowemu DVD, zachowującemu oryginalny format obrazu ${ }^{2}$. Obcięte kadry nagle dopełnione zostają o brakujące treści, zyskują głębię i równowagę kompozycji - okoliczność ta, jak mało która, zachęca do ponowienia refleksji nad tym osobliwym dziełem, zaklasyfikowanym powszechnie jako ogniwo serii tematyzującej mit Elektry, rzadziej natomiast kierującym wzrok ku pogardzanemu D'Annunziu i może nazbyt dobrze zakamuflowanemu Wagnerowi.

\section{Etruska Elektra}

W opinii Massima Fusilla ${ }^{3}$ głos wiodący powierzony został w filmie Viscontiego mitowi Elektry, ze szczególnym uwzględnieniem zreinterpretowanej postaci Orestesa (Orina) z trylogii O'Neill'a, który - jako bohater rozbity, zmierzający do autodestrukcji - miałby stanowić punkt odniesienia dla Gianniego z filmu Viscontiego. Osiagany przez film efekt ambiwalencji postulowany przez samego Viscontiego ${ }^{4} \mathrm{i}$ być może z tego względu nieustannie podkreślany przez wielu badaczy jego twórczości - łączy, zdaniem Fusilla, Btędne gwiazdy... z innymi psychologizującymi XX-wiecznymi wersjami mitu Atrydów. Konsekwentnie jednak autor przyznaje rację reżyserowi co do zadeklarowanej przez niego zasady transpozycji: nie przepisuje on mitu, a tylko wzbogaca fabułę o szereg różnego rodzaju powierzchownych analogii (,analogie schematiche"5) do antycznej tragedii, które na tle innych przetworzeń literackich - dodaje od siebie włoski badacz - zdają się najmocniej

${ }^{2}$ Podstawą cytowania jest wydanie płytowe DVD: Vaghe stelle dell'Orsa, reż. Luchino Visconti, scen. Suso Cecchi D’Amico, Enrico Medioli, Luchino Visconti, zdj. Armando Nannuzzi, scenogr. Mario Garbuglia, wyst. Claudia Cardinale (Sandra Dawdson), Jean Sorel (Gianni Wald-Luzzati), Michael Craig (Andrew Dawdson), Renzo Ricci (Antonio Gilardini), Marie Bell (matka) i in., produkcja: Franco Cristaldi dla wytwórni Vides, Włochy 1965, format obrazu: 1.78:1, film czarno-biały, NTSC, czas trwania: 100 min, dystrybucja: Kinokuniya Company Ltd., 2003.

${ }^{3}$ M. Fusillo, „Sorella amata, Elettra tradita”. Visconti e il mito degli Atridi, [w:] Visconti a Volterra. La genesi di „Vaghe stelle dell'Orsa”, a cura di V. Pravadelli, Torino 2000, s. 69-82.

${ }^{4}$ Zob. L. Visconti, Un dramma del non essere, [w:] Vaghe stelle dell'Orsa... di Luchino Visconti, a cura di P. Bianchi, Bologna 1965, s. 31-32: „[...] questo film è un "giallo» diverso dal consueto. [...] Insomma un "giallo», ove tutto è chiaro all'inizio e oscuro alla fine [...]".

${ }^{5}$ Tamże, s. 32. Visconti nie zmierzał tu bynajmniej do zachowania konsekwencji. Jak sam wyjaśniał na przykładzie głównej bohaterki i jej ojczyma, tym, co łączy Sandrę z Elektra jest przyczyna jej gniewu, a tym, co łączy Gilardiniego z Egistem, jest fakt umiejscowienia 
obecne. W 1977 roku Gianni Rondolino pisał, że właśnie ambiwalencja osiagana podobnie jak w dramacie: poprzez zintensyfikowanie konfliktu racji aż do nierozwiązywalności - stanowi kluczową kategorię poetyki Viscontiego, tym ciekawsza, że realizowaną z pełnym zawierzeniem mocy fabularnej, „faktom, dialogom i działaniom”, i drobiazgowo rozplanowanej strukturze formalnej ${ }^{6}$. Rzec by można, że u Viscontiego wszystko przeczy Kracauerowskiemu życzeniu „nieforemności” i „epickości” w ukształtowaniu fabuły filmowej, umiejaccej rzekomo tylko jako taka chwytać życie w jego zmienności. Czyż więc rzeczywiście efekt nierozstrzygalności jest w Błędnych gwiazdach... unikalny i w dodatku nadajacy się do testowania pokrewieństwa Viscontiego i XX-wiecznych dramaturgów, bioracych na warsztat mit Elektry? Watpliwe. „Droga Sandro, ukochana siostro, zdradzona Elektro" - tymi słowami rozpoczyna się list pożegnalny Gianniego do Sandry, projektowany w niezrealizowanej pierwszej wersji scenariusza ${ }^{7}$. „Elektra pogrzebaną" nazwie tę samą bohaterkę Franco Cristaldi, producent filmu, odmawiając jej odwagi jakiegokolwiek czynu'

W świetle historii rodu Atrydów - nie precyzując wszakże, które z ujęć greckich tragików byłoby bliższe Viscontiemu - film Błędne gwiazdy... odczytuje również Stefan Łanowski, stawiając go obok ekranizacji Eurypidesowej Elektry Michalisa Cacoyannisa z roku 1962:

W tym dramacie konflikty rodu Atrydów przeniesiono na tło umierającego starego miasta, w czas, na który rzutuja jeszcze widma ostatniej wojny. Orestesem i Elektra, Giannim i Sandra, jest para sierot po sławnym uczonym żydowskim zamordowanym w obozie koncentracyjnym. Rodzeństwo odnajduje się po latach niewidzenia w ojczystym domu w Volterra koło Florencji (Sandra jest zamężna [...]), odkrywa powoli prawdę, że ojca wydała w ręce oprawców matka w spółce z jednym ze swoich kochanków, teraz administratorem majątku rodziny. $\mathrm{W}$ tych ramach rozgrywa się stary dramat, obraz zagłady rodziny na tle ruin starego miasta. Jest tu i przekra-

postaci poza ścisłym kręgiem rodzinnym. „Sandra ma oblicze oskarżycielki, Gilardini pozwanego, w rzeczywistości jednak ich pozycje równie dobrze można by odwrócić (tamże)”.

${ }^{6}$ G. Rondolino, Visconti e il nuovo cinema degli anni sessanta, [w:] Visconti. Il cinema, a cura di A. Ferrero, Modena 1977, s. 132-133.

${ }^{7}$ Vaghe stelle dell'Orsa... di Luchino Visconti..., s. 89. Także w trzeciej wersji scenariusza, choć już nie w tak mocnym dramaturgicznie momencie akcji, jakim jest jej rozwiąanie, imię to pojawia się w ustach Gianniego (M. Giori, Scandalo e banalità. Rappresentazioni dell'eros in Luchino Visconti (1963-1976), Milano 2012, s. 109). Moja numeracja kolejnych wersji scenariusza, spośród których - dodajmy - opublikowane zostały tylko pierwsza i ostatnia, odwołuje się do klasyfikacji Gioriego (tamże, s. 89-90).

${ }^{8}$ Okres pracy na planie zdjęciowym trwał - jak wynika z opublikowanego Giornale di bordo Rinalda Ricciego (Vaghe stelle dell'Orsa... di Luchino Visconti..., s. 93-128) - od 26 sierpnia do 17 października. Sąd Cristaldiego pochodzi z listu do reżysera datowanego na 9 października: „Altro che Elettra tradita: questa è un'Elettra sepolta!” (Lettera di Franco Cristaldi, n. di archivio Fondo Visconti: C30-009370, [w:] Visconti a Volterra..., s. 291). 
czające ramy miłości brata i siostry uczucie Gianniego i Sandry, i wielkie oskarżenie Sandry rzucone matce, niezrównoważonej psychicznie, i wiele jeszcze z posiewu wiecznej historii tego wątku. Sandrą-Elektra jest Claudia Cardinale ${ }^{9}$.

Nasuwa się natychmiast kilka uwag do tego filologicznego komentarza, który - jak w przypadku większości streszczeń utworów fabularnych - przesuwa akcenty znaczeniowe, chcąc uzupełnić istotne luki i niedopowiedzenia wbudowane przez Viscontiego w materię opowieści. Po pierwsze, Gianni i Sandra nie są tożsami z Orestesem i Elektrą. Po wtóre, w żadnym wypadku nie można powiedzieć, że Sandra „powoli” dochodzi do odkrycia jakiejś prawdy na temat okoliczności zdrady ojca. A nawet jeśli jej nienawiść w stosunku do matki i ojczyma uznać za umotywowana faktycznie popełniona przez nich zbrodnia, nie jest ona efektem żadnego z przedstawionych zdarzeń, nie stanowi elementu dramaturgicznego; to raczej wyraz utrwalonego już od dawna przekonania Sandry, z którym konfrontowane sa inne postaci postawione na jej drodze, artykułującego się nawet $\mathrm{w}$ jej epatującej od początku pewną wrogością fizycznej ekspresji. Warto nadmienić, że skrajnie stylizowana gra aktorska Claudii Cardinale, utrzymujaca afekt oburzenia nieustannie jakby na zewnątrz postaci, w nagłości jej ruchów i nadwyrazistości mimiki, nawiązywać może wprawdzie - jak sugeruje Stefania Parigi - do typu aktorstwa epoki kina niemego ${ }^{10}$, ale też przede wszystkim w swej nienaturalności przywodzi na myśl literacko-symboliczna porywczość Izabelli z powieści Gabriele'a D'Annunzia Może tak, może nie. Poniższy fragment, ukazujacy bohaterkę w analogicznym w stosunku do filmu momencie akcji - po wyjściu z jeszcze przed chwilą rozpędzonego samochodu i tuż przed wkroczeniem w zastygły świat przeszłości, uosabiany przez nieczynny już, zrujnowany pałac innej Izabelli - wydaje się stanowić coś w rodzaju podkładu literackiego dla sceny filmowej, w której Sandra staje u bramy swej rodzinnej posiadłości:

Rynek, samotny, rozciagał się pomiędzy domostwami, kościołami, wieżami; okrywały go wielkie cienie, zdające się czerpać oddech w przeszłości wspaniałej, wyrafinowanej, świetnej, zdradzieckiej i morderczej. Jaskółki rzucały okrzyki prawie obłędne. Pałac był zamknięty. I nagle zdało się tej nerwowej istocie, że zagrzebane tam było najskrytsze jej przeznaczenie. Dysząc, skoczyła na ziemię i podobna wygnance, która w nędzy powraca, poczęła uderzać w drzwi obiema zaciśniętymi pięściami.

- O, co za gwałtowność, Izabello, sprawisz sobie ból. Przestraszysz stróża, który nie wpuści tak późno małej warjatki okrytej kurzem.

${ }^{9}$ Eurypides, Elektra, przeł. i oprac. S. Łanowski, Wrocław 1969, s. LXXII.

${ }^{10}$ S. Parigi, Vaghe stelle dell'Orsa... Il deposito della memoria, [w:] Il Cinema di Luchino Visconti, a cura di V. Pravadelli, Venezia 2002, s. 224-225. 


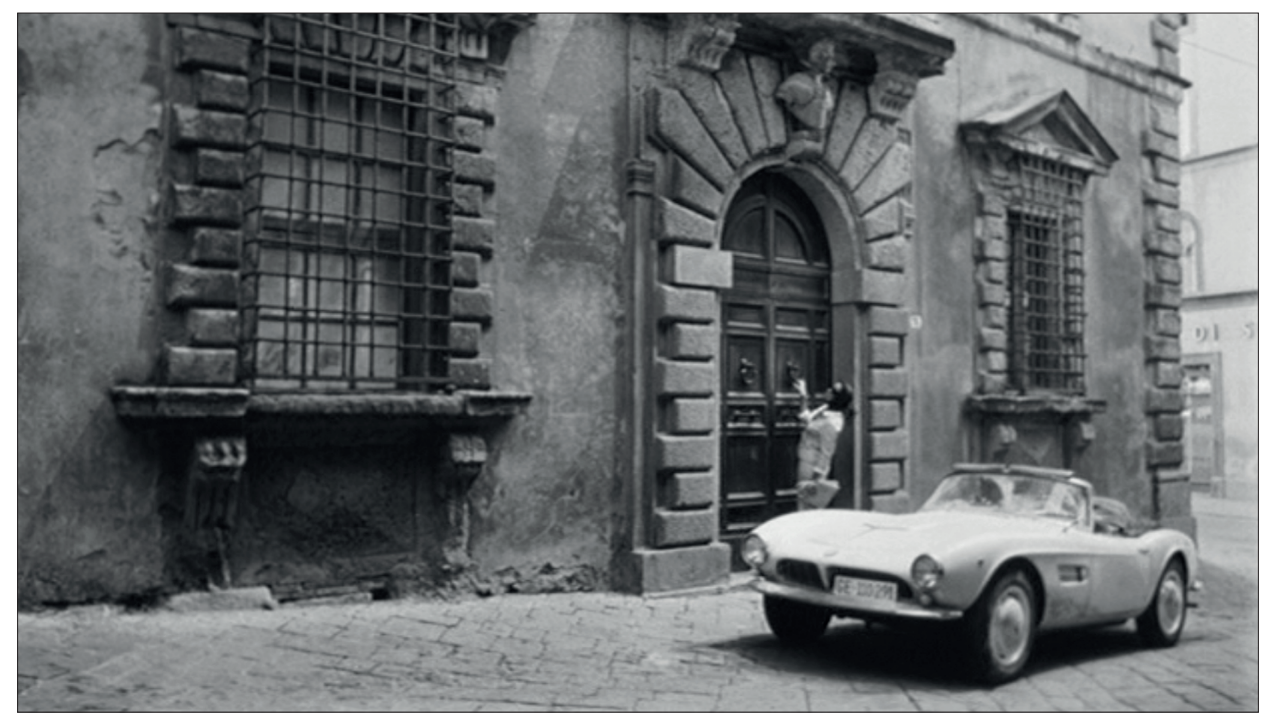

Il. 1. Vaghe stelle dell’Orsa, reż. Luchino Visconti, Włochy 1965

Źródło: Vaghe stelle dell’Orsa, reż. Luchino Visconti, DVD, produkcja: Franco Cristaldi dla wytwórni Vides, format obrazu: 1.78:1, film czarno-biały, NTSC, czas trwania: 100 min, dystrybucja: Kinokuniya Company Ltd., 2003

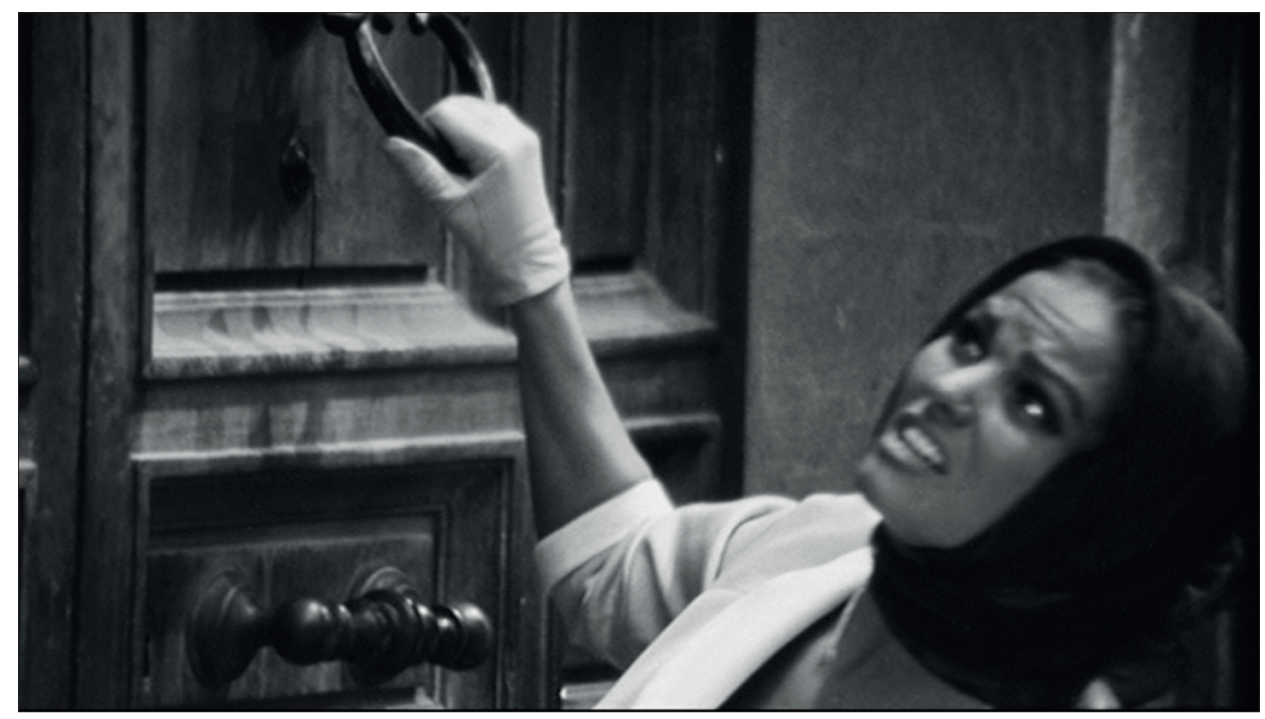

Il. 2. Vaghe stelle dell’Orsa, reż. Luchino Visconti, Włochy 1965

Źródło: Vaghe stelle dell’Orsa, reż. Luchino Visconti, DVD, produkcja: Franco Cristaldi dla wytwórni Vides, format obrazu: 1.78:1, film czarno-biały, NTSC, czas trwania: 100 min, dystrybucja: Kinokuniya Company Ltd., 2003 
Paolo śmiał się, porwany jednak tą żywiołowościa, tą różnorodnością form i dźwięków, tym zapałem i uniesieniem, które zdawały się czynić z miejsca gdzie się znajdowała świat cały.

- Jest tu dzwonek, wyrzekł nieśmiały głos.

$[\ldots]$

Niecierpliwa zdziwiła się, później wybuchnęła śmiechem. Poszukała dzwonka, pociagnęła z całej siły. Dźwięk rozległ się i powtórzył w pustce. Usłyszeli kroki, mruczenia, obrót klucza w zamku; drzwi się otworzyły, stróż stanął w progu. Brodaty i łysy był pospolita postacia Czasu bez kosy i klepsydry. Nie dała mu ust otworzyć, lecz owionęła natychmiast nieprzepartym błaganiem: - Proszę pozwolić nam wejść! Wejdziemy na chwilę. Odjedziemy przed nadejściem nocy. Może już nigdy tu nie powrócimy ${ }^{11}$.

W niewzruszoności, z jaka od samego początku filmu Sandra wyznaje credo nienawiści, być może najbardziej przypomina ona swą protoplastkę z dzieł greckich tragików. Ostatecznie zaprzątało ich przecież pytanie o możliwość i słuszność pomsty - jej przebieg stanowił pożywkę właściwej akcji ${ }^{12}$. Inaczej w filmie Viscontiego: ani Sandra, ani Gianni nie wracaja do rodzinnego domu, by szukać odwetu za dawne krzywdy, toteż wątek tragicznej śmierci ojca - element strukturalny wprost odsyłajacy do historii Agamemnona - szybko schodzi na dalszy plan, a raczej podlega w toku akcji raz mocniejszemu, raz słabszemu przesłanianiu. Istnienie więzów krwi między bratem a siostrą nie nakłada na Gianniego żadnych obowiązków. Oboje przyjeżdżaja do Volterry nie po to, by cokolwiek wyjaśniać czy też stawiać czoła jakiemukolwiek zewnętrznemu niebezpieczeństwu. Celem jest udział w ceremonii uświęcającej pamięć ojca przez odsłonięcie jego pomnika oraz przekazanie miastu okazałego ogrodu, który ma stać się parkiem publicznym. Jako ludzie dorośli prowadzą oni względnie uporządkowane życie, odcięte od spraw przeszłości. Dramat zaczyna się z chwila gdy po przekroczeniu rodzinnego progu odżywają dawne wspomnienia i oplatające je namiętności. Jeśli coś tutaj dokonuje się stopniowo, to właśnie osuwanie się w przeszłość, kryjąca jeszcze jedną domniemana zbrodnię: skłonność kazirodczą Gianniego i Sandry. Wydawać się może, że antyczny sztafaż pełni u Viscontiego podwójną funkcję: z jednej strony

${ }^{11}$ G. D’Annunzio, Może tak, może nie (Forse che si, forse che no), przeł. H. Żółkiewska, Warszawa 1912, s. 19-20.

12, „[...] Ajschylos jako pierwszy przypisał Elektrze ważną rolę w dziele zemsty na zabójcach Agamemnona w drugiej części swej trylogii. Występuje ona wprawdzie tylko w pierwszej części sztuki, ale jest tu obok Orestesa główną postacia planu dramatycznego [...]. Główną zasługa Ajschylosa jest [...] stworzenie obrazu buntowniczej dziewczyny, która pozostając w domu, musi mieszkać przez długie lata pod jednym dachem z mordercami ojca i czekać na powrót brata-mściciela”. R.R. Chodkowski, Wstęp, [w:] Sofokles, Elektra, przeł., wstępem i przypisami opatrzył R.R. Chodkowski, Lublin 2008, s. 14. 
zasłania, z drugiej odsłania właściwe dno fabuły; kieruje uwagę widza ku historii pomsty, ale też nosi w sobie potencjał przetworzenia ku treści pierwotnie w antycznym tworzywie nieobecnej, jak o tym świadczą dalsze losy tematu w XX wieku ${ }^{13}$. W oku cyklonu - by wyrazić się obrazowo znajduje się $u$ Viscontiego wątek incestu brata i siostry, nałożony niczym kolejna warstwa na istniejące już pasma tradycji literackiej: romantyczne, modernistyczne i współczesne. Jak trafnie zauważa Alicja Helman, dopiero „sieć kulturowych odniesień" czyni z prostej w istocie fabuły opowieść „wieloznaczną i skomplikowaną"14.

Z dokumentacji pracy nad dziełem wynika, że Visconti nie miał jasności, czy relację incestualną między rodzeństwem odsłonić już na początku filmu ${ }^{15}$ i czy uczucie ma być wzajemne ${ }^{16}$. Historię tych wahań omówił szczegółowo Mauro Giori. Dla nas istotne jest jedno kluczowe ustalenie: temat incestu był jedynym od początku do końca wyraźnie wyodrębnionym elementem fabularnym filmu, łączącym się ponadto bezpośrednimi więzami z od dawna okupującym wyobraźnię artysty dramatem Szkoda, że jest ladacznica Johna Forda (wystawionym przez Viscontiego w Paryżu w roku 1961 i zablokowanym następnie przez włoską cenzurę) i powieścią Gabriele’a D’Annunzia Może tak, może nie, której ekranizację artysta brał najwyraźniej pod uwage po odrzuceniu projektu adaptacji XVII-wiecznego tekstu ${ }^{17}$. Zdaniem Gioriego tło tragedii greckiej nie stanowiło więc - z genetycznego punktu widzenia odniesienia prymarnego, lecz wtórne, umocnione głosami wrogiej naonczas D'Annunziowi krytyki ${ }^{18}$. W funkcji elementu stabilizującego „incestowa” linię fabularna, począwszy od drugiej wersji scenariusza, pojawia się jako moment zawiązania akcji scena spotkania Gianniego i Sandry w ogrodzie, w której Visconti osiagnął najpewniej to, co nazwie później „mocnym dramatycznym punktem wyjścia"19. Stopił w niej obraz czułego spotkania ko-

${ }^{13}$ Zob. E. Frenzel, Orests Rache [hasło], [w:] tejże, Stoffe der Weltliteratur. Ein Lexikon dichtungsgeschichtlicher Längsschnitte, Stuttgart $2005^{10}$, s. 697-702. Zob. także na temat wykorzystania tematów imiennych w XX-wiecznej powieści i (wspólnych dla filmu i powieści) konsekwencji tego posunięcia: J. Abramowska, Serie tematyczne, [w:] tejże, Powtórzenia $i$ wybory. Studia z tematologii i poetyki historycznej, Poznań 1995, s. 40-41.

${ }^{14}$ A. Helman, Urok zmierzchu. Filmy Luchina Viscontiego, Gdańsk 2001, s. 193.

${ }^{15}$ Zob. M. Giori, dz. cyt., s. 94-95.

${ }^{16}$ Tamże, s. 98-99.

17 Tamże, s. 86.

${ }^{18}$ Przyczyną wrogości były oczywiście powiązania autora z reżimem faszystowskim. Rehabilitacja D’Annunzia jako pisarza rozpoczyna się we Włoszech z końcem lat 60. O nawiązaniach filmu Viscontiego do twórczości D’Annunzia jako pierwszy pisał ostrożnie Guido Aristarco w artykule Gli spiriti e le vaghe stelle, opublikowanym w roku 1965 na łamach „Cinema Nuovo" (nr 178, s. 441-443). Zob. M. Giori, dz. cyt., s. 87.

19, „.... lo spunto drammatico a forti tinte”. L. Visconti, Un dramma del non essere..., s. 32. 
chanków z Ajschylosową wizją spotkania u grobu ojca ${ }^{20}$, nadając epizodowi szczególnej wyrazistości, potrzebnej do tego, by mógł on odegrać w pamięci widza rolę nieustannie aktualizowanego tła, „na którym wszelkie aluzje do kazirodztwa nabierają znamion pewnego prawdopodobieństwa" ${ }^{21}$. Rzecz to już zdecydowanie anegdotyczna, ale warta $\mathrm{w}$ tym miejscu napomknienia, że także współpracownicy Viscontiego znali zamysł reżysera: kolejny po Lamparcie film z Claudią Cardinale miał być filmem o kazirodztwie ${ }^{22}$. Tyle tylko, że w toku pracy punkt ciężkości przeniesiony został z przedstawiania efektów wykroczenia na przedstawianie poszlak, dochodzenie do prawdy - a raczej do uświadomienia sobie niemożności jej odkrycia pod gruzami przeszłości.

„W Błędnych gwiazdach Wielkiej Niedźwiedzicy - pisze Marta Piwińska oglądamy współczesną Elektrę i Orestesa zakochanych w sobie" ${ }^{23}$. Nawet jeśli trudno w pełni zgodzić się ze skrótowymi uwagami badaczki na temat filmu Viscontiego, wskazany przez nią kierunek poszukiwań w obrębie tradycji romantycznej jest bez wattpienia słuszny. Materia antyczna, wtopiona w mit zakochanego rodzeństwa, wypowiada się w filmie w rozpoznawalnych toposach literatury romantycznej, takich jak ten osnuty wokół obrazu lustrzanego odbicia. Pisząc o rodzeństwie, które u Viscontiego „wpatruje się, milcząc, we własne odbicie w wodzie"24, Piwińska stawia protagonistów filmu obok Manfreda i Astarte z poematu Byrona, Eleonory i jej adoratora z opowiadania Poego Eleonora oraz obok Siegmunda i Sieglindy z Wagnerowskiej Walkirii, koncentruje się jednakże tylko na pojedynczym obrazie istotnie, ciążącym ku lekturze odseparowującej go z całości - podczas gdy romantyczna figura organizuje od strony ikonograficznej cała centralna scenę filmu, czyli drugie (po rozpoznaniu w ogrodzie) spotkanie Sandry i Gianniego na osobności, rozgrywane w przestrzeni starożytnej etruskiej cysterny, miejscu dawnych dziecinnych zabaw. Przypomina ono jako żywo dekorację do którejś z romantycznych oper:

${ }^{20}$ Tylko w Ofiarnicach Ajschylosa spotykamy bohaterkę na grobie ojca i sam grób wyobrażony na scenie. Jak mówi składająca ofiarę Elektra: „Nienawiść gorzką - kryję./ I tylko mój tajony płacz/ pod chust osłoną pana czci -/ I tak, w ukryciu, srebrzy mię żałobny szron...". Ajschylos, Ofiarnice. Trylogii część druga, [w:] tegoż, Tragedie, przeł. i oprac. S. Srebrny, Warszawa 1954, s. 396, w. 91-94. „Sofokles, który w swej sztuce skupi się na samej Elektrze i jej przeżyciach, inspirację do tego mógł niewątpliwie znaleźć w tragedii Ajschylosa. W Choeforach bowiem jakby w zarodku sa zawarte główne motywy, dominujące w postawie, przeżyciach i działaniach bohaterki Sofoklesa" (R.R. Chodkowski, dz. cyt., s. 15).

${ }^{21}$ A. Helman, dz. cyt., s. 207.

${ }^{22}$ M. Giori, dz. cyt., s. 108.

${ }^{23}$ M. Piwińska, Kochana siostra, [w:] tejże, Złe wychowanie. Fragmenty romantycznej biografii, Warszawa 1981, s. 302.

${ }_{24}$ Tamże, s. 306. 


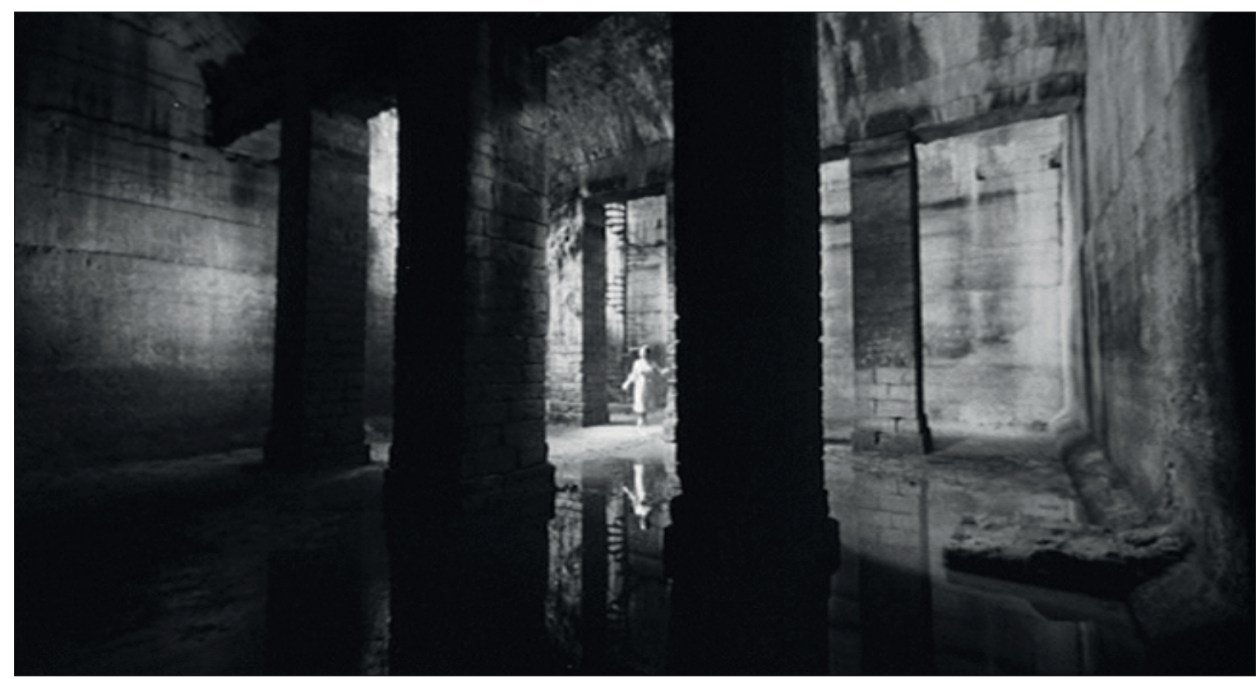

Il. 3. Vaghe stelle dell’Orsa, reż. Luchino Visconti, Włochy 1965

Źródło: Vaghe stelle dell’Orsa, reż. Luchino Visconti, DVD, produkcja: Franco Cristaldi dla wytwórni Vides, format obrazu: 1.78:1, film czarno-biały, NTSC, czas trwania: 100 min, dystrybucja: Kinokuniya Company Ltd., 2003

Być może żadna inna scena filmu tak otwarcie nie demonstruje, jak romantyczny mit miłości staje się łudzącą oko dekoracja, osłaniającą co najwyżej - bo na pewno nie wyrażająca - właściwa treść pokazywanych zdarzeń. Sandra i Gianni stają nad wodną taflą i spoglądają w dół, nie może tu być jednak mowy o rozpoznawaniu czy przypieczętowywaniu ich wzajemnej miłosnej tęsknoty poprzez uczynienie jej na romantyczną modłę niedosięgła w wizualnym zwielokrotnieniu. Obraz Viscontiego - istotnie, cytujący - to raczej komentarz wygłaszany na zgliszczach romantycznego mitu aniżeli jego aktualizacja. Wystarczy spojrzeć na przebieg epizodu. Bohaterowie pokazani są w jednej ze „scen dziecięcych” - on czeka na nią jak kiedyś, zostawiwszy wcześniej w umówionej skrytce listowną wskazówkę, ona zaplata warkocz, wkłada dziewczęcą sukienkę i biegnie niczym na schadzkę, ukradkiem oglądając się za siebie - ale ich dialog szybko wypada z tonu wspomnieniowego, obrastając zgoła inną treścia. Sandra chce rozmawiać z bratem „w domu”, który dla Gianniego uosabia właśnie dawna kryjówka (,To jest nasz dom”). Replika siostry („Był, już nim nie jest”) aż nazbyt plakatowo pokazuje, że osią dramatu tych dwojga jest stosunek do przeszłości, a raczej niemożność ponownego jej doświadczania i rozumienia po zatrzaśnięciu się drzwi dzieciństwa. Dalej toczy się już gra nie tyle dzieci, ile dorosłych-dzieci, świadomych znaczenia każdego swego gestu. Gianni zsuwa z palca Sandry ślubna obrączkę i wkłada ją na swój palec, co wywołuje gwałtowny protest kobiety 
i kieruje jej myśli w stronę wydarzeń poprzedniego dnia. Visconti umieszcza w tym miejscu akcji (00:58:55) centralną retrospekcję ze spotkania córki z chora psychicznie matka, która - doprowadzona do granic oburzenia nazywa swoje dzieci dwoma potworami i wrogami. Szybki najazd kamery odcina moment retrospekcyjny od ukazujących się nagle w jego świetle dalszych działań rodzeństwa: Gianni zasłania Sandrze usta, prosząc, by nic więcej nie mówiła. Zaznaczmy, że tego typu najazdy i odjazdy kamery oraz wielokrotnie wykorzystywane w całym filmie nagłe zmiany ogniskowej (tzw. zoomy) układają się w swoisty wzorzec, szyfr wizualny, służący - jak można sądzić - stylistycznemu wyakcentowaniu tematu incestu przy jednoczesnym nieodsłanianiu go w sposób bezpośredni. A więc tutaj niejako obustronnie - bo i w świecie przedstawionym, i w sposobie jego wyrażania - tłamsi się próbę wypowiedzenia treści w sposób jednoznaczny. Gianni kompulsywnie wraca do wspominania przeszłości. Tym razem w eliptycznej mowie bohatera na pierwszy plan wysuwa się kwestia uwolnienia: tak jak niegdyś pośpieszył na pomoc siostrze zamkniętej w podziemnej kryjówce, tak i teraz ja ratuje. Musi ona tylko zajrzeć do salonu matki, gdzie zostawił do przeczytania swoją autobiograficzną powieść, mająca przynieść wyjaśnienie i wyzwolenie od głosów z przeszłości. To w tym miejscu dialogu, zostawiając poza kadrem realny świat - pełna obaw Sandrę i pewnego siebie Gianniego, który nie przestaje mówić (,Zrozumiesz także i to, dlaczego nie chcę, byś

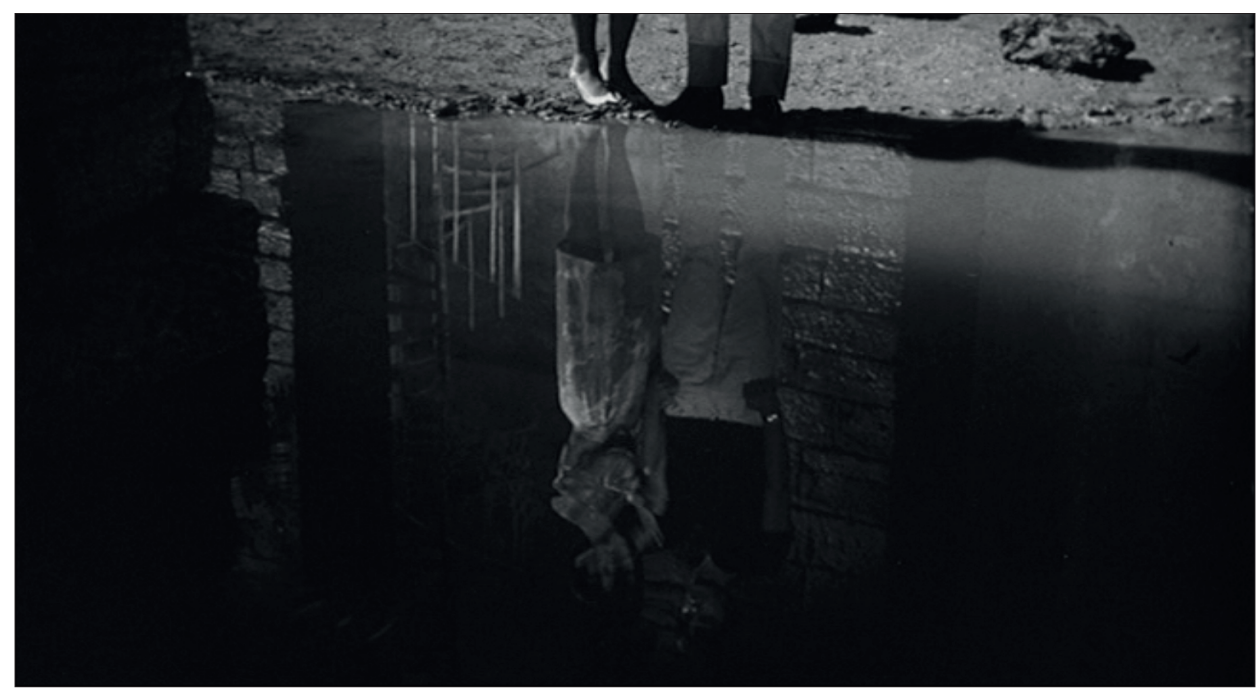

Il. 4. Vaghe stelle dell’Orsa, reż. Luchino Visconti, Włochy 1965

Źródło: Vaghe stelle dell’Orsa, reż. Luchino Visconti, DVD, produkcja: Franco Cristaldi dla wytwórni Vides, format obrazu: 1.78:1, film czarno-biały, NTSC, czas trwania: 100 min, dystrybucja: Kinokuniya Company Ltd., 2003 
mi powiedziała, co widziałaś wczoraj. Wiem. Ale nie chcę o tym mówić. Widzisz, Sandro, są sprawy, od których się uwolniłem, na zawsze”) - Visconti umieszcza obraz odbijającego się w wodzie rodzeństwa.

Jak sugeruje reżyseria, słowa Gianniego stanowią całość z wizualnym cytatem romantycznym, a więc obraz powinien być interpretowany wraz $\mathrm{z}$ nimi. Visconti przewidział dla tego momentu wymowny dialog ruchu kamery i postaci: najpierw odjazd wydobywający statyczne lustrzane odbicia, później skupione rejestrowanie odejścia Sandry w głąb kadru, jakby dla potwierdzenia słów Gianniego o uwolnieniu się od pewnych spraw, i wreszcie zdający się zaprzeczać wszystkiemu, co dotąd pokazane, najazd kamery, który pozbawia stojącego Gianniego utrzymywanego dotychczas w polu widzenia zaczepienia w podłożu i odsłania w wodnym odbiciu jego wzrok, utkwiony w spoczywający na palcu pierścionek siostry. „Może tak, może nie" - zdaje się mówić reżyser, a wejście w lustro wody, które ów moment odejścia-przyjścia pokazuje w odwróceniu, zdaje się wprowadzać widza nie w otchłań namiętności splątanych tożsamości, lecz w świat odbity w powieści Gianniego. Perspektywa widzenia jest więc tu jedno-, nie dwupodmiotowa, a już na pewno nie - jak u romantycznych bohaterów - wspólnopodmiotowa. Zamykając historię swego młodzieńczego życia na kartach powieści, bohater próbuje z pełną świadomością dokonać uwięzienia miłosnej historii w lustrze wyłącznie swojej własnej pamięci - podnoszac zgubny afekt do rangi literackiego konstruktu i tym samym odcinając go od życia. Siostra, jak wiemy z fabuły, udaremni tę próbę z obawy przed skandalem. Gianni wygłasza w filmie dwie znamienne kwestie, które odsłaniaja go - mimo deklaracji Viscontiego ${ }^{25}$ - jako przewodnika widza, a przy tym rzucają światło na skomplikowana kwestię transmisji romantycznej w Btędnych gwiazdach Wielkiej Niedźwiedzicy. Pierwsza pada podczas spotkania przy kominku, gdy nazywa on po imieniu problem związany z pisaniem o samym sobie: ,dziecko, które chciało zakosztować namiętności dorosłego, zamieniło się w dorosłego... niezdolnego wrócić do niewinności tamtego czasu" ${ }^{26}$. Druga wybrzmiewa w czasie spaceru z Andrew po osypiskach Volterry: „Życie na prowincji

${ }^{25}$ Zamierzeniem Viscontiego było zachowanie dystansu obserwatora względem prezentowanych wydarzeń i względem postaci. Porównywał tę sytuację z podglądaniem krzątaniny insektów i przywoływał ją w swych wypowiedziach o filmie niejednokrotnie: M. Rusconi, Il Leone d'oro al magnetofono, „Sipario” 1965, nr 234, s. 11; A. Aprà et al., Intervista con Luchino Visconti, „Filmcritica” 1965, nr 159-160, s. 440; s. n., „Vaghe stelle dell'Orsa nell'itinerario di Visconti, „Cinema Nuovo” 1966, nr 180, s. 111. Cyt. za: M. Giori, dz. cyt., s. 113-114. Do „częściowego utożsamiania się” z Giannim przyznawał się wszakże w trzecim z cytowanych tu źródeł, tj. anonimowym wywiadzie z czasopisma „Cinema Nuovo” (zob. M. Giori, dz. cyt., s. 113).

${ }^{26}$ „Ho voluto fissare queste sensazioni in una favola, ma il bambino che sapeva provare la passione d'un adulto, è diventato un adulto... incapace di ritrovare l'innocenza d'un tempo...”. L. Visconti, Sceneggiatura del girato, [w:] Vaghe stelle dell'Orsa... di Luchino Visconti..., s. 175. 
jest wszędzie takie samo. Ze swoimi desperackimi namiętnościami, które wydają się nierealne, gdy są daleko, a w tym samym momencie, w którym nagle wracają znów cię obezwładniają. Choćby nawet minęło sto lat...”27.

\section{"Lecz któż jest Amnonem?"}

Dążenie męża Sandry, Andrew, do wykrycia prawdy na temat relacji łączącej brata i siostrę decyduje o tym, że akcja filmu nabiera charakteru zagadki ${ }^{28}$. Visconti z pewnością nie konstruuje tu właściwej kryminałowi misternej sieci poszlak i rozwikłań - wezwany do opowiedzenia o filmie, zdaje się sięgać po termin „kryminał” tylko z braku trafniejszego określenia, gdyż natychmiast dopowiada, co pod tym pojęciem rozumie, powołując się na Króla Edypa jako przykład fabuły obnażającej winę bohatera najmniej podejrzanego. Celem reżysera było uniknięcie jednoznaczności w ocenie działań postaci i ukazanie ukrytego potencjału winy w każdej z nich, a także w samym widzu, względnie postawienie pod znakiem zapytania myślenia w kategoriach winy i kary ${ }^{29}$. Mówiąc o kryminale, chciał on zapewne podkreślić realizowaną w filmie dramaturgię stopniowego przybliżania się do majaczącego w oddali faktu, którego wyłączna interpretacja jest wszakże niemożliwa. Obudowaną wokół tego niepewnego faktu (czyli incestu) akcję, posuwającą się do przodu trzema pasmami - pasmem zdarzeń związanych z (1) przybliżaniem się ceremonii funeralnej ku czci ojca, (2) z działaniami Andrew zmierzajacymi do pojednania zwaśnionych stron, a w rezultacie przynoszącymi katastrofę, (3) z jakościową przemianą relacji między Sandrą i Giannim - reżyser osadza w strukturze literackich odniesień, która z jednej strony działa stabilizująco, krystalizująco, z drugiej natomiast dynamizuje się nieustannie w toku percepcji, gdyż odniesienia te nakładane

${ }^{27}$ „La vita di provincia è la stessa dapertutto. Con le sue passioni esasperate, che sembrano impossibili quando se n'è lontani, ma che ti ripiombano addosso nel momento stesso in cui ritorni. Fosse anche dopo cent'anni...”. Tamże, s. 153.

${ }^{28}$ Visconti posłużył się na określenie typu dramatu przedstawianego w filmie sformułowaniem „quiz di anime” (L. Visconti, Un dramma del non essere..., s. 34). Pisząc o zagadce, idę tropem niemieckiego tłumaczenia (zob. L. Visconti, Ein Drama über das Nicht-Sein, übers. von Marianne Schneider, [w:] Visconti. Schriften, Filme, Stars und Stills, hrsg. von Marianne Schneider u. Lothar Schirmer, München 2008, s. 57).

${ }^{29}$ Visconti kilkakrotnie akcentuje w swym programowym tekście Un dramma del non essere, że podejmowane przez filmowych bohaterów rozrachunki z przeszłością rzucaja światło na współczesne włoskie społeczeństwo, stające przed koniecznością zrozumienia własnego momentu historycznego, rozliczenia się z minionych zbrodni i określenia, dla kogo jest w nim miejsce, a dla kogo nie. Tak można by, wyostrzając dość ogólnie ujęte myśli reżysera, rozumieć jego przesłanie i obronę filmu przed zarzutem eskapizmu. 
są warstwowo i bez szczególnej dbałości o czytelną rekonstrukcję kontekstu, z którego zostały przejęte ${ }^{30}$. Zobaczmy, jak w praktyce działa ten mechanizm.

Wracamy do sceny pałacowej z ekspozycyjnej części powieści D’Annunzia. Bohaterowie, wspomniana już Izabella - partnerka filmowej Sandry i Paolo Tarsis - jej ukochany - konfrontują się tu z na wiele sposobów wypowiadanym przeczuciem śmierci, zaklinanym zresztą przez nich samych: rodzi się ono na gruncie erotycznego nienasycenia, które kulminuje w scenie drapieżnego pocałunku przypieczętowanego krwią i spuentowanego wtargnięciem dwojga osób, młodszej siostry Izabelli, Vany, i jej brata, Aldo. D’Annunzio nadaje temu epizodowi znaczenie wyraźnie symboliczne, co więcej-przerzuca w tym miejscu pomost między początkiem a zakończeniem swego obszernego utworu, spinając całość klarowną kompozycją. Dramat miłosny jest $\mathrm{u}$ niego dramatem czworga, a nie - jak u Viscontiego - trojga: niesyta siebie, dzika i kapryśna miłość Izabelli i Paola zderza się z miłością czystą i niewinną melancholijnej Vany do tegoż samego Paola i dopiero na końcu powieści zdemaskowaną miłością incestualną Izabelli i Alda. Upodlona, doprowadzona do obłędu Izabella, w czwartym z opisanych patetycznie siedmiu ostatnich dni udręki towarzyszącego jej męczarni Paola, cytuje w obecności lekarza wyimki z Księgi Samuela:

Nagle, po rodzaju niezrozumiałego monologu, rzekła z wyrazistościa, która przerażała ją samą: „A jednak, grzech, o który mię oskarżacie, popełniłam; i nie powinnam się usprawiedliwiać". Wówczas, patrząc jej głęboko w oczy, powtórzyłem pytanie: „Któż jest Amnonem?” Uśmiechnęła się tajemniczo, uśmiechem, który wśród jej stygmatów jest, że tak powiem, promieniem cienia, bardziej tajemniczym niż promień światła, który widzimy na świętych obrazach.

Później wygłosiła wolno inny werset, wydobywając go z pamięci jak z ognia: „A Amnon był w wielkiej trwodze, stał się chorym z miłości do Tamary, swej siostry". Wówczas powtórzyłem z naleganiem: „Lecz któż jest Amnonem?” Skoczyła jednym z tych skoków, które czynią ją podobną do wichru płomieni i popiołów, krzycząc: „Mój brat! mój brat!”

Pierwszy sygnał antycypujący takie rozwiązanie to przedstawienie pokrewieństwa wrażliwości i fantazji między Izabellą a Aldem, którzy jako jedyni podczas zwiedzania pałacowych ruin prowadzą grę we wskrzeszanie

${ }^{30} \mathrm{O}$ kluczowej dla wszelkiego rodzaju intertekstualności kategorii tzw. interpretantu (,zespół czynników, który określa w nowym kontekście stosunek do tekstu przejętego”, „rama, w która przywołany element został ujęty") pisał Michał Głowiński (tegoż, O intertekstualności, [w:] Poetyka i okolice, Warszawa 1992, s. 105, 116). Uobecnianie się w danym dziele treści wskazujących na zapożyczenie z innego tekstu może przebiegać - przypomnijmy - w różnym stopniu jawnie. Jakoś jednak musi o sobie dawać znać, skoro odwołanie staje się dla odbiorcy czytelne i dające się rozpoznać jako „element budowy znaczeniowej tekstu, w którym ono się dokonuje" (tamże, s. 98). 
przeżytej rzekomo przed czterystu laty przeszłości, doznając „chorobliwej przyjemności mieszania rzeczy żyjących z rzeczami zmarłymi, łączenia dwu różnych wytworności, grzebania w dwu wewnętrznych jaźniach" ${ }^{31}$. Izabella - tak jak Sandra Viscontiego - miała wówczas splatać włosy w warkocze i owijać je dookoła głowy dla podobania się bratu ${ }^{32}$. Powiązania między postaciami powieściowymi i filmowymi nie ograniczają się, jak widzimy, do przejęcia wybranych cech literackiego portretu zewnętrznego - traktowanych często wybiórczo i uruchamianych jedynie punktowo ${ }^{33}-$ lecz sięgają relacji strukturalnych, które wzmacniają te pierwsze w funkcji cytatu. Visconti uruchamia część konstelacji osobowej, od razu ogniskując ją wokół problemu incestu, który u D’Annunzia zaczyna tak naprawdę znaczyć dopiero na końcu utworu. Owszem, wcześnie zaznacza się, że Aldo budzi zazdrość Paola, tak jak w filmie Gianni budzi - z tych samych względów podejrzliwość Andrew:

Paolo Tarsis patrzył w tę twarz młodego strąconego boga tak bardzo ludzkiemi namiętnościami umęczona; i uraza jego twardych i świadomych lat trzydziestu pięciu zwiększała się wobec tego wdzięku niepokojącego jak gorączka rekonwalescencji. Każdy ruch młodzieńca ku siostrze budził w nim nieskończony niepokój ${ }^{34}$.

Niemniej jednak ten trop fabularny pozostaje przez większą część powieści nieaktywny, przynajmniej nie bezpośrednio. Powraca w zwieńczeniu, by zadać decydujący cios uczuciu, które ściaga lotnika na niziny ${ }^{35}$ - przywrócić go triumfalnie życiu - a do tego czasu ukrywa się pod maskami Izabelli: otacza ja nimbem tajemniczości i czyni niedosięgła dla miłości Paola, wielokrotnie bolejącego z powodu niemocy i niezupełności łączącego ich uczucia.

Śmiertelne przeznaczenie Izabelli - przedstawione w zwielokrotnieniu w cytowanej już rozbudowanej scenie otwierajacej powieść - D’Annunzio szyfruje w postaci „dewizy Pauz”, odczytywanej z pałacowego sufitu nieprzypadkowo właśnie przez Alda:

${ }^{31}$ G. D’Annunzio, dz. cyt., s. 48.

${ }^{32}$ Tamże, s. 49.

${ }^{33}$ Spójrzmy na najbardziej zwarty fragment charakteryzujacy postać Izabelli: „Jakież przymioty pociagały ku niej bardziej, niż ta rozmaitość postaci, ta moc przeobrażeń, ta zdumiewająca sztuka kłamania, połączona z przerażającą żądzą cierpienia, te maski tragiczne z dziecięcym wdziękiem naprzemian, to zachowanie królowej i niewolnicy, ta wściekłość i ta wiotka bezbronność, te wszystkie kontrasty i połączenia, które czyniły ją nieobliczalna, jak połączenie niezgodnych elementów?". Tamże, s. 178.

${ }^{34}$ Tamże, s. 58.

${ }^{35}$ Paolo jest lotnikiem, zdecydowanie sprzysiężonym z postępem i nowoczesnościa podobnie jak Andrew Viscontiego, o którego wychyleniu w przyszłość możemy wnosić na podstawie narodowości (Amerykanin) oraz przydanych mu atrybutów (BMW, trzymane pod ręka prospekty, amatorska kamera filmowa), zdradzających, że mamy do czynienia z turystą błądzącym w obcym sobie świecie. 
- Jeśli się nie mylę jest tu klucz kontraltowy; później oto cztery znaki tempa, potem znaki trzech pauz wartości zmniejszającej: dwa, jeden cały, pół; potem pauza wartości minimalnej, potem trzy pauzy w porządku odwrotnym, nakoniec znak podwójnego riturnelu.

$[\ldots]$

- Jaka dziwna i głęboka dewiza! Izo, droższą ci była po nad wszystkie inne [...].

- Jest mi zawsze droga - rzekła czarodziejka. Jest to wartość tego, o czem nie mówiłam, nie mówię i nie powiem nigdy.

Uśmiechnęła się z twarzą zwróconą profilem, nawpół w świetle, nawpół w cieniu.

- Od dnia dzisiejszego biorę znów godło Pauz; — dodała — teraz chodźmy ${ }^{36}$.

Dopiero w dramatycznym finale powieści okaże się, że dewiza była bezpośrednio powiązana z tajemnica incestu Izabelli i Alda. Wyjawiona przez siostrę zbrodnia wydobyła się niejako z milczenia muzycznych pauz i przemówiła adekwatnym do przedmiotu wulgarnym językiem. Trzykrotnie „wyraz ohydny, ten, który bezcześci kobietę publiczna, zagrzmiał brutalnie w czterech ścianach. Później zaległo milczenie, jak po razie, który ogłusza” ${ }^{37}$. Pozostała część szyfru dopełnia się w rękoczynie. Dotkliwie pobita i zgwałcona przez kochanka Izabella jest tą sama, która podczas zwiedzania ruin pałacu po raz pierwszy poczuła w ustach smak krwi.

Jak widać, Visconti nie wzoruje się na D’Annunziu ani w zakresie przeprowadzenia, ani w zakresie rozwikłania incestowej intrygi, choć trudno nie dopatrzyć się analogii między sceną pobicia Izabelli przez Paola, rozgrywaną równolegle z samobójstwem Vany, a przybliżającą do tragicznego denouement sceną bezradnej szamotaniny Sandry napastowanej przez Gianniego pod statuetką Amora i Psyche (podobna jest też - nadmieńmy relacja między matką a córką $\left.{ }^{38}\right)$. Wraz z odjazdem Andrew i spaleniem przez Gianniego - niedoszłego pisarza-skandalisty - rękopisu powieści runęła przegroda oddzielająca przeszłość od teraźniejszości. Romantycznie uwznioślone uczucie do siostry karleje i wypowiada się teraz już tylko w języku żądzy: tchnaccych grozą gestach bliskich gwałtowi. Niezrozumiany przez siostrę, wtrącony przez osoby postronne w rolę lubieżnika i bezwstydnika, najwyraźniej świadomy niebezpieczeństwa, jakie w obliczu zaistniałej sytuacji niesie z sobą jego powieść, Gianni przeistacza się z doskonale panującego nad swymi emocjami mężczyzny w postać infantylną i dekadencko-demoniczną zarazem. W odpowiedzi na próbę fizycznego wyładowania niemocy

${ }^{36}$ Tamże, s. 43-44 (zachowano oryginalną grafię).

${ }^{37}$ Tamże, s. 362-363.

${ }^{38}$ Wydobycie postaci matki to kolejne ogniwo umożliwiające przejście między mitem Elektry a fabułą filmu: w powieści rolę wroga przejmuje macocha („druga żona Curzia Lunati” - podobieństwo do nazwiska Waldo Luzzati jest godne odnotowania), nazywana Szakalem, która w ostatniej partii utworu urasta wraz z ojcem do rangi prześladowcy córki z pobudek finansowych. Zob. G. D’Annunzio, dz. cyt., s. 332-333, 372, 413-414. 
ze strony mężczyzn Sandra - równolegle do przemiany Gianniego - urasta do rangi jedynej postaci dojrzałej, zdolnej odciąć się od społecznej opinii na temat domniemanej kazirodczej przeszłości poprzez uczynienie jej - mówiąc skrótowo - częścią historii Elektry. Visconti przygotowuje tę zamianę miejsc jak wytrawny dramaturg, inscenizując w kulminacyjnym momencie „kryminalnej” akcji scenę rozprawy przy rodzinnym stole. Zagadka - zda-
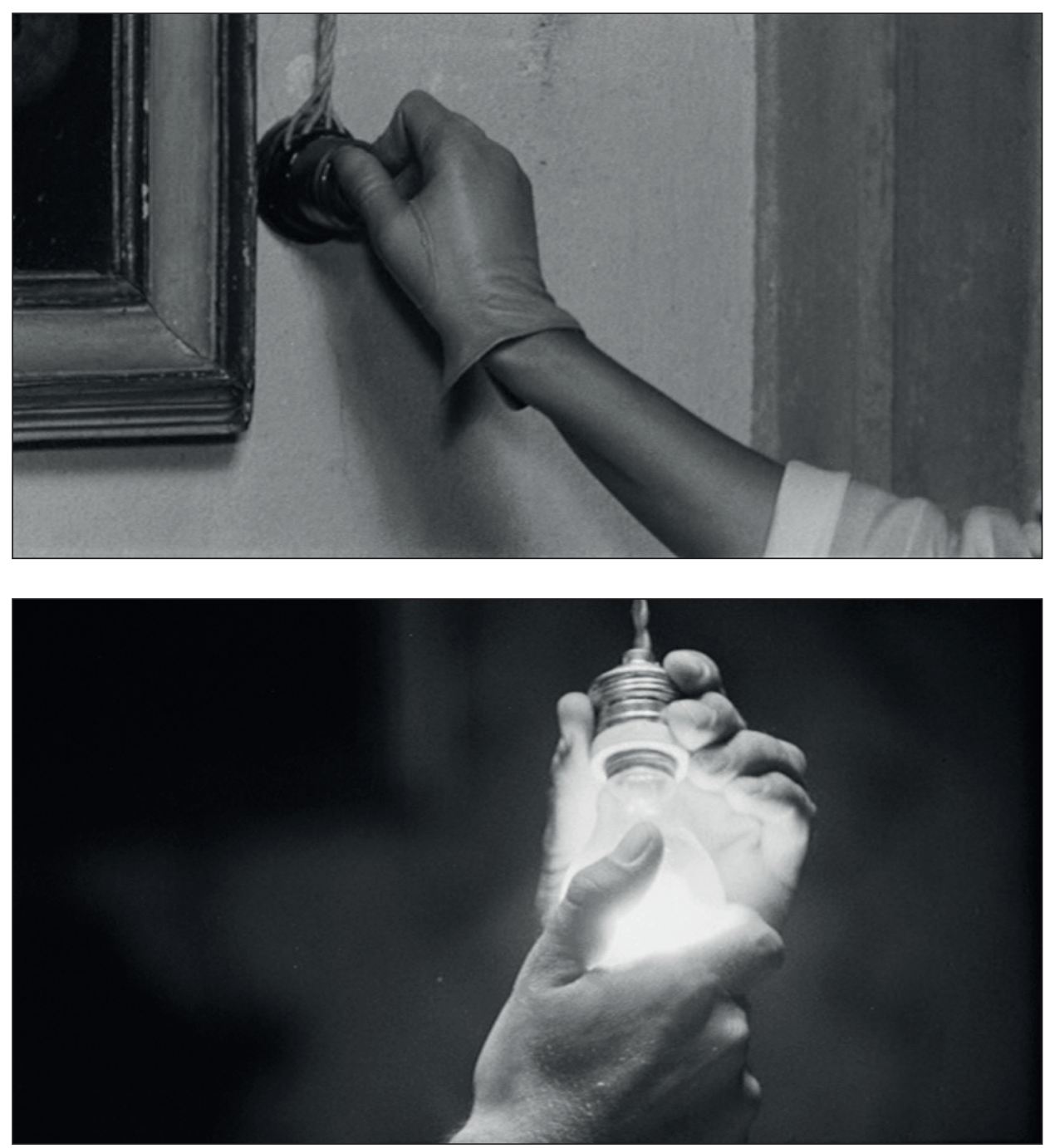

Il. 5-6. Vaghe stelle dell’Orsa, reż. Luchino Visconti, Włochy 1965

Źródło: Vaghe stelle dell’Orsa, reż. Luchino Visconti, DVD, produkcja: Franco Cristaldi dla wytwórni Vides, format obrazu: 1.78:1, film czarno-biały, NTSC, czas trwania: 100 min, dystrybucja: Kinokuniya Company Ltd., 2003 
wałoby się - zostaje rozwiązana, ale przemiana postaw protagonistów znów zamienia rezultat dochodzenia w zagadkę.

Podobnie jak D’Annunzio reżyser szyfruje relację między bratem a siostrą na poziomie kompozycyjnym: przerzuca wizualny pomost między częścią ekspozycyjną dzieła a fragmentem zarezerwowanym dla perypetii przez powtórzenie treści pewnego nacechowanego symbolicznie ujęcia. Gdy Sandra tuż po przyjeździe do Volterry staje u progu pierwszej izby, przekręca włącznik światła. Wraz z wydobytymi z mroku przedmiotami ożywają uczucia pogrążone dotąd w ciemności. Analogicznie pod koniec filmu, jeszcze przed dojściem do rozpętującej demony rozmowy z ojczymem, Gianni przekręca żarówkę mająca służyć za prowizoryczne oświetlenie. Nie trzeba dodawać, jakie znaczenie oczywiście, możliwe do osiagnięcia w ramach filmowego realizmu - ma w kontekście akcji ukształtowanej na wzór rozwiązywania zagadki zapalanie światła.

\section{Zagadka Siegmunda i Sieglindy}

Mówiliśmy o zachodzącej w ostatniej tercji filmu, a dokładniej po „romantycznym" spotkaniu w cysternie, istotnej zamianie miejsc między Sandrą a Giannim. Nagłe przestawienie ogniskowej - budujące wewnattrz dzieła kolejny układ zwierciadlany, tym razem na poziomie dramaturgicznym stanowi część reżyserskiej strategii kodowania incestu. Nie może dziwić, że centralne dla tego tematu sceny to rozgrywane na osobności epizody intymnych spotkań między rodzeństwem:

I Spotkanie w ogrodzie: 00:18:28-00:22:52

II Spotkanie w cysternie: 00:55:32-01:00:36

III Spotkanie przy kominku: 01:03:52-01:11:43

Zestawione w jednym ciagu, ujawniają one na tyle dokładną i spójna koncepcję inscenizacyjna, że zaryzykować można tezę, iż budują łącznie czytelne nawiązanie do innego jeszcze źródła literackiego: Walkirii Richarda Wagnera, pierwszej części tetralogii Pierścień Nibelunga. Naznaczone cielesną bliskością trzy spotkania Sandry i Gianniego wzorowane są w warstwie wizualnej na słynnym duecie miłosnym Siegmunda i Sieglindy z I aktu Wagnerowskiego dramatu muzycznego.

\section{Spotkanie I}

Wietrzną aurę etruskiej (i D’Annunziańskiej ${ }^{39}$ ) Volterry, miasta skazanego na zagładę, Visconti daje po raz pierwszy w pełni odczuć w scenie

${ }^{39}$ Począwszy od II księgi akcja powieści Może tak, może nie przenosi się do Volterry. 

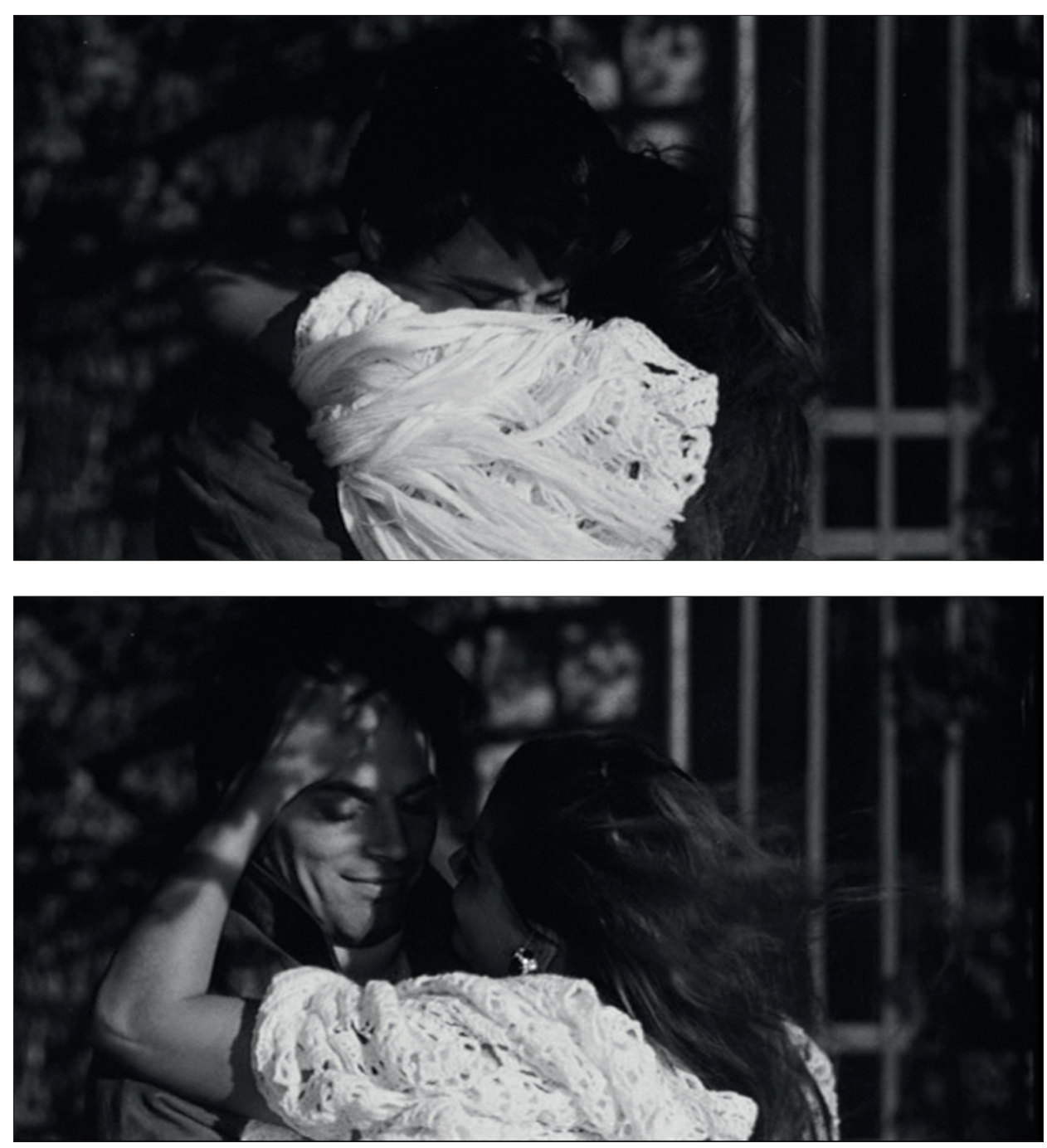

Il. 7-8. Vaghe stelle dell’Orsa, reż. Luchino Visconti, Włochy 1965

Źródło: Vaghe stelle dell’Orsa, reż. Luchino Visconti, DVD, produkcja: Franco Cristaldi dla wytwórni Vides, format obrazu: 1.78:1, film czarno-biały, NTSC, czas trwania: 100 min, dystrybucja: Kinokuniya Company Ltd., 2003

spotkania Sandry i Gianniego w ogrodzie okalającym rodzinną posiadłość. Niepostrzeżenie z głowy Sandry wychodzącej na spotkanie nieznajomego zsuwa się skromnie zawiązana chustka - to już drugi raz, kiedy wspomnienie Gianniego powiązane zostaje ze zdjęciem nakrycia głowy ${ }^{40}$ - po czym

${ }^{40}$ Pierwsze ma miejsce w 12 minucie filmu: gdy z ust służącej pada informacja, że Gian$\mathrm{ni}-\mathrm{w}$ przeciwieństwie do siostry - wielokrotnie bywał w rodzinnej posiadłości w ostatnim 


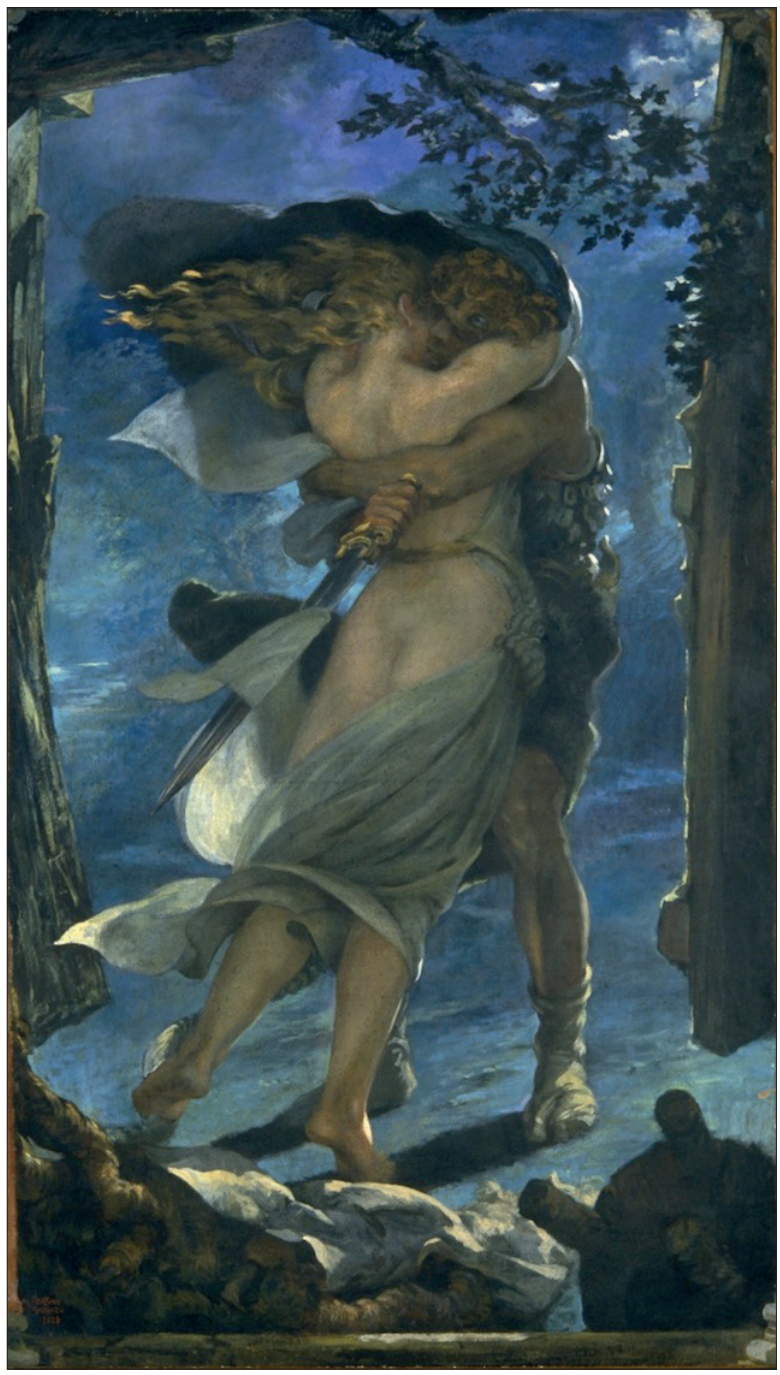

Il. 9. Mariano Fortuny y Madrazo, Walkiria. Siegmund i Sieglinda w objęciach, 1928

Źródło: domena publiczna

gwałtowny powiew rozplata jej włosy, tak że tworzą odtąd stylistyczna całość z trzepoczącym na wietrze białym płótnem przesłaniającym statuę zmarłego ojca, podrywanymi w górę frędzlami ażurowego szala spowija-

czasie, zaskoczona Sandra pojawia się, niczym zdemaskowana, z dopiero co zdjętą chusta w ręku. Tego rodzaju grę przesłonami Visconti lubił szczególnie i nieraz wykorzystywał, także w tworzeniu układów zwierciadlanych. 
jącego ramiona kobiety i nieustannie się kołyszącymi gałęziami drzew. W długich włosach siostry dawno nie widziany brat może ukryć twarz, tak by oboje wydawali się jednym ciałem. Nocna scena, jak sugerował Giorgio Pestelli ${ }^{41}$, przywodzi na myśl ilustracyjny obraz Mariano Fortuny y Madrazo, przedstawiający spotkanie odnajdującego się po latach rozłąki boskiego rodzeństwa Wälsungów ${ }^{42}$.

W libretcie Wagnera - przypomnijmy - drzwi otwiera podmuch namiętności, „wiosenny czas”. Łatwiej go, rzecz jasna, zmetaforyzować w tekście niż przedstawić wizualnie, toteż i na obrazie, i w filmie przybiera on postać gwałtownego wiatru, nawiązującego do „już cichnącej zawiei” towarzyszącej przybyciu Siegmunda w niegościnne progi domu Hundinga ${ }^{43}$. Niecywilizowana miłość - jakkolwiek tylko u Wagnera i Fortuny - przenosi nas w „bezkształtną ogólność natury albo w to, co spoczywa przed historią i kultura, w świat prehistoryczno-mityczny" 44 :

Łagodną bronią maj/ zniewala dziś świat:

zimę precz przepędził,/ poskromił wiatr -

czy dziw, że na jego rozkaz/ wierzeje ciężkie ustapią?

Nie oprze się nic,/gdy maj zechce wejść.

Do swojej siostry/ przemkną się tu;/ miłość zwabiła maj:

tajona dotąd/ w zakątkach serc,

dziś może zaśmiać się w głos.

Brat przyszedł uwolnićl swą siostrę najmilsza,

dzielący ich mur/ już w gruzach legł.

Złączyli się.

Znów razem sa - z miłością spotkał się maj! ${ }^{45}$

W gestykulacji Sandry dopatrzyć się można transkrypcji znaczących ruchów Sieglindy, pieczołowicie opisanych w didaskaliach Wagnerowskiego

${ }^{41}$ G. Pestelli, Il pianoforte di Franck: la voce del passato, [w:] Visconti a Volterra..., s. 88.

${ }^{42}$ Chodzi o obraz olejny Walkiria. Siegmund $i$ Sieglinda $w$ objęciach (1928) - wyraz rozkwitłej po pobycie w Bayreuth w roku 1892 pasji dla odtwarzania tematów podejmowanych w dramatach muzycznych Wagnera. Zob. Guillermo de Osma, Mariano Fortuny. His life and work, trans. by S. Berg, London 2015, s. 67-81.

${ }^{43}$ Didaskalia do I aktu informuja: „Przez jakiś czas scena pozostaje pusta; na zewnątrz zawieja, już cichnąca. Zygmund otwiera drzwi wejściowe z zewnątrz i wchodzi. Jeszcze z ręka na ryglu rozgląda się po izbie; zdaje się do cna wyczerpany; jego strój i wygląd świadczą o tym, że ucieka. Nie widząc nikogo, zamyka za sobą drzwi, z największym wysiłkiem człowieka śmiertelnie znużonego podchodzi do paleniska i rzuca się na skórę niedźwiedzią". R. Wagner, Walkiria, przeł. M. Łukasiewicz, Warszawa 1988, s. 6.

${ }^{44}$ N. Wagner, Wagner Theater, Frankfurt am Main-Leipzig 1998, s. 94. Cyt. za: J. Kühnel, „Braut und Schwester bist du dem Bruder”. Der Geschwisterinzest in der „Völsunga saga“, bei Richard Wagner und Thomas Mann, [w:] Les Interdits. Actes du Colloque international des 1 $1^{\text {er }}, 2$ et 3 Mars 2012 à Amiens, Amiens 2012, s. 139.

${ }^{45}$ R. Wagner, dz. cyt., s. 34. 
dramatu muzycznego: „zarzuca mu ramiona na szyję i z bliska patrzy mu w oczy”, jest „tuż przy jego twarzy”, „odgarnia mu włosy z czoła”46. Wspólna obu scenom - teatralnej i filmowej - jest także koncepcja operowania biela i czernią: Sandra w obszernym białym szalu; Sieglinda „w białej szacie” na tle całkowitej ciemności, którą dopiero po chwili rozświetli blask księżyca w pełni. W przykuwającym uwagę swą ewidentną teatralnościa, przecząca wszelkim zasadom realistycznej inscenizacji filmowej, momencie przejścia dwojga aktorów ze stania do siedzenia, Gianni - tak jak Siegmund - „z łagodna stanowczościa przyciaga ku sobie” Sandrę ,i zmusza, by siadła przy nim" ${ }^{47}$. Rozpoznanie dokonuje się w cieniu wspomnienia ojca $-\mathrm{w}$ tetralogii jest nim Wotan-Wälse, który dał początek rodowi Wälsungów, w filmie Emanuele Wald Luzzati, z którym wszakże - inaczej niż u Wagnera - związana czuje się przede wszystkim Sandra. Wzmianka o ojcu nie jest u Viscontiego motywem służącym rozpoznaniu się dwojga kochanków - nie pochodzi bowiem z materii romantycznej, lecz z mitycznego tworzywa osnutego wokół losów Elektry i Orestesa.

\section{Spotkanie II}

ZYGLINDA

Widziałam w rzece/ odbicie swe

i dziś je znowu oglądam:

jak kiedyś w zwierciadle wód

- w tobie przeglądam się dziśs

ZYGMUND

Tyś obraz jest,/ którym w sercu miał

Analizowane wcześniej ujęcie ze sceny w etruskiej cysternie zyskuje status nawiązującego do dramatu muzycznego Wagnera ze względu na to, że jest częścią większego ciąu logicznego. Topos romantyczny ulega zatem w filmie Viscontiego uszczegółowieniu - pod warunkiem, że zjawisko „przeświecania" fabularnego Walkirii przyjmie się za rzeczywiście zachodzące i sensotwórcze. Hipotezę analogii wzmacnia okoliczność, że obaj męscy bohaterowie - Siegmund i Gianni - mówią o „uwolnieniu” siostry ${ }^{48}$, wbudowanym w czytelną ramę fabularna: w historię zemsty, w której istotna rolę odgrywa wspólnota krwi. W filmie jest to oczywiście zemsta oczekiwana tylko przez Sandrę-Elektrę.

\footnotetext{
${ }^{46}$ Tamże, s. 36.

${ }^{47}$ Tamże, s. 32.

48 „Die bräutliche Schwester/ befreite der Bruder“ (tamże, s. 35).
} 
Lecz dzisiaj zemsta/ dana obojgu!

Śmiejmy się -/ radości to czas,

gdy trzymam ciebie w ramionach,

gdy jeden rytm bije serc! ${ }^{49}$

\section{Spotkanie III}

W rozgrywanej przy palącym się kominku scenie w salonie matki, w czasie której Gianni przechodzi od oskarżenia siostry o drobnomieszczańskie lęki związane z publikacją powieści do obnażenia swej duszy, intymne plany bliskie znów skłaniają widza do skupienia się na ruchu postaci. W tym zakresie po raz kolejny natykamy się na wyraziste paralelizmy - tyle że punktem odniesienia nie jest już miłosny epizod Walkirii, lecz naśladująca go finalna scena noweli Thomasa Manna $Z$ rodu Wälsungów ${ }^{50}$.

Zastosowane w filmie miękkie złote światło, oblewające twarze Gianniego i Sandry, sprzyja zacieraniu anatomicznych różnic w wyglądzie postaci. Jak w obu przywołanych utworach, także tutaj zewnętrzne podobieństwo protagonistów opowieści - choć wydobyte jedynie sztucznie - powinno sygnalizować szczególne pokrewieństwo wewnętrzne. Kiedy już wybrzmia najostrzejsze słowa rozmowy i dialog - sprowokowany pytaniem Gianniego

${ }^{49}$ Tamże, s. 32.

${ }^{50}$ Polemizując z teza, iż utwór Manna stanowi parodię Pierścienia Nibelunga, Erwin Koppen zwracał uwagę na istotną różnicę dotyczącą sposobu funkcjonowania w obu dziełach motywu incestu: o ile w tetralogii generuje on - jako centrum fabularne rozłożystej epickiej materii - dalsze dzieje bogów i powołanych przez nich do życia śmiertelników, o tyle w noweli stanowi „punkt dojścia i klimax”, „docelowy motyw organizujacy całe opowiadanie” i skłaniający do postawienia kluczowego pytania: kto kogo parodiuje? Zob. E. Koppen, Dekadenter Wagnerismus. Studien zur europäischen Literatur des Fin de siècle, Berlin-New York 1973, s. 148. „Tak jak w swych wcześniejszych, a przede wszystkim późniejszych dziełach, w [opowiadaniu] $Z$ rodu Wälsungów fragmenty przejęte ze źródeł literackich, względnie literacko-muzycznych, Thomas Mann ułożył kalejdoskopowo obok wycinków naśladowanej rzeczywistości, przeżyć biograficznych itd. Ta gra efektami puzzli i odbić jest wszakże w [noweli] $Z$ rodu Wälsungów w równie nikłym stopniu celem samym w sobie jak w innych utworach" (tamże, s. 149). Przypomnijmy, iż utwór napisany został w roku 1905 i najpierw, tj. w roku 1921, opublikowany został - ze zmienionym zakończeniem - jako prywatna luksusowa edycja limitowana $\mathrm{z}$ dołaczonymi trzydziestoma litografiami Thomasa Theodora Heinego. Dopiero w 1958 roku, a więc w bliskim sąsiedztwie powstawania filmu Viscontiego, trafił do sztokholmskiego wydania zbiorowego opowiadań Thomasa Manna i odtąd zaczęto publikować go bez względu na zakaz autora. Pierwsze wydanie noweli z przywróconym jej pierwotnym zakończeniem ukazało się w roku 2004 w Große kommentierte Frankfurter Ausgabe. Zob. J. Kühnel, dz. cyt., s. 141. Visconti - dodajmy - znany był ze swego zamiłowania do twórczości Manna - przykładem chociażby wystawione za zgodą pisarza przedstawienie teatralne Mario i czarodziej. 

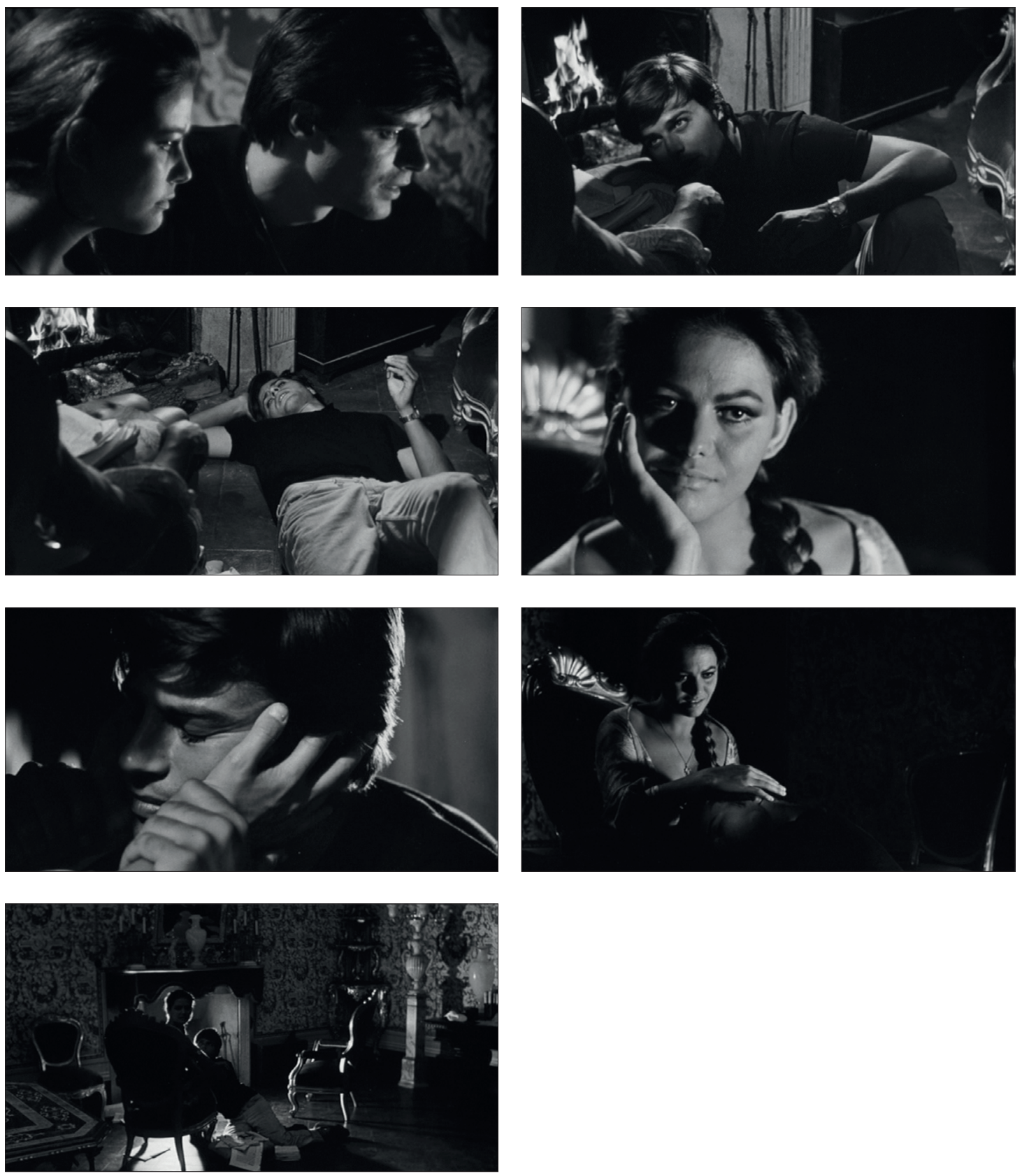

Il. 10-16. Vaghe stelle dell’Orsa, reż. Luchino Visconti, Włochy 1965

Źródło: Vaghe stelle dell’Orsa, reż. Luchino Visconti, DVD, produkcja: Franco Cristaldi dla wytwórni Vides, format obrazu: 1.78:1, film czarno-biały, NTSC, czas trwania: 100 min, dystrybucja:

Kinokuniya Company Ltd., 2003 
(„Dlaczego starałaś się mnie unikać przez te wszystkie lata?”) - powoli zacznie przybierać postać wzajemnego słuchania wspomnień, statyczna grę postaci zdominują trzy charakterystyczne układy figur: (1) Sandra siedzaca ze złączonymi kolanami w fotelu i Gianni leżący u jej stóp z ramieniem podłożonym pod głowę; (2) Sandra opierająca podbródek na ręce w geście rozmarzonego zasłuchania $\mathrm{w}$ zwierzenia brata, z majaczacym na twarzy uśmiechem; (3) Gianni z głową spoczywająca na kolanach siostry, która gładzi go po włosach.

W całej scenie blask bijący z kominka zmysłowo oświeca ciało Sandry, kładąc się wielkimi plamami na obnażonym głębokim dekolcie i odsłoniętych nogach, oraz wymownie koresponduje z przytoczonym przez Gianniego cytatem z książkowego manuskryptu ${ }^{51}$, opowiadającym niejako na drugim planie - w postaci „obcych” słów wplecionych w rozmowę - o gwałtownym uścisku miłosnym brata i siostry. Tym samym, który Thomas Mann ukazuje $\mathrm{w}$ swej noweli jako zdarzenie rozgrywające się w świecie przedstawionym, przydając mu następująca introdukcję:

Za sobą dostrzegł w lustrze skórę polarnego niedźwiedzia, wyciagającego łapy przed łóżkiem. Odwrócił się, tragicznie rozwlekłym krokiem przeszedł tam i po chwili wahania padł na skórę jak długi, podkładając ramię pod głowę.

Przez chwilę leżał całkiem spokojnie; potem podniósł się na łokciu, oparł policzek na wąskiej, czerwonej ręce i trwał tak, zatopiony w widoku swego odbicia w lustrze naprzeciwko, w szafie. Zapukano. Wzdrygnął się, zaczerwienił, chciał się zerwać. Ale potem opadł na powrót, znów opuszczając głowę na wyciagnięte ramię i milczał.

Sieglinda weszła. Oczy jej zaczęły go szukać po pokoju, nie znajdując od razu. W końcu dostrzegła go na niedźwiedziej skórze i przeraziła się.

- Gigi... co ty robisz? Czyś chory? - Podbiegła do niego, pochyliła się nad nim i gładząc ręką jego czoło i włosy, powtórzyła:

- Chyba nie jesteś chory?

Potrząsnął głową i spojrzał na nią z dołu, leżąc nadal oparty na własnym ramieniu, głaskany przez nią. Przyszła w pantofelkach, na pół już rozebrana do snu, ze swego pokoju, który znajdował się w korytarzu naprzeciw jego drzwi. Pod koronkami gorsetu dostrzegł drobne jej piersi, których skóra miała barwę przydymionej pianki morskiej ${ }^{52}$.

Kłopotliwy do odtworzenia na żywo, rzec by można: wynaturzony w swym wyrafinowaniu układ postaci w scenie opisanej przez Manna, przenoszacy w realia luksusowej rezydencji familii Aarenholdów fragment operowej

${ }^{51}$ „Mi buttavo sul corpo compiacente di mia sorella, come se fosse quello di un nemico da sbranare, senza mai essere soddisfatto dell'amplesso...”. L. Visconti, Sceneggiatura del girato..., s. 173 .

${ }^{52}$ T. Mann, Z rodu Wälsungów, przeł. M. Kurecka, [w:] tegoż, Opowiadania, przeł. M. Kurecka et al., Warszawa 1963, s. 295-296 (podkreślenia - A.I.). 
stylistyki, stanowi przedtakt do wynaturzonego aktu miłosnego. Czytelne dla znających fabułę Walkirii elementy wystroju wnętrza (zwłaszcza jeden: rozpostarta na podłodze niedźwiedzia skóra), a ponadto prześmiewcze sformułowania użyte do opisu akcji (zwłaszcza jedno, łączące „tragicznie rozwlekły krok" Siegmunda Aarenholda zmierzającego w stronę futrzanego posłania z krokiem „śmiertelnie znużonego” protagonisty dramatu Wagnera) niedwuznacznie odsyłają do przedstawienia, które bohaterowie noweli - bliźnięta żydowskiego pochodzenia, Siegmund i Sieglinda - mieli okazję obejrzeć kilka godzin wcześniej i którego opis u Manna wykazuje rysy jawnie parodystyczne.

Nie ma u Viscontiego niedźwiedziej skóry - jest za to iskrzacy się ogień i kładący się przy nim bohater; nie ma bohatera wpatrującego się w swe lustrzane odbicie w szafie - jest za to bliższy operowemu Siegmundowi Gianni patrzący w wodną kałużę z głębi etruskiej cysterny i Sandra przeglądająca się (w pozie Mannowskiego Siegmunda) we wspomnieniach brata; jest też wzmianka o chorobie „godnej romantycznego bohatera" ${ }^{53}$. Choć o pochodzeniu Sandry i Gianniego - elemencie fabularnym wyjątkowo ważnym w utworze Manna ${ }^{54}$ - od pierwszych scen zaświadcza noszony przez oboje na łańcuszku symbol gwiazdy Dawida, nie ma u Viscontiego ani śladu parodii rodem ze skandalizującej swym żydowskim kontekstem noweli. Można by nawet uznać, że ta powierzchowna wskazówka podkreślająca tożsamość krwi i motywująca wątek rodowej zemsty kieruje uwagę tyleż w stronę Manna, co w stronę mitu Atrydów. Nie ulega wątpliwości, że wbrew deklarowanym zamiarom nie udało się reżyserowi rzeczywiście sproblematyzować w filmie kwestii „kompleksu wyższości rasy żydowskiej”55. Wybór żydow-

${ }^{53}$ „Vedi, Sandra... mi è successa una cosa molto strana il giorno che seppi del tuo matrimonio... un malessere... una specie di crisi convulsiva, degna di un eroe romantico. Sai se mi era mai successo da bambino?" L. Visconti, Sceneggiatura del girato..., s. 174.

${ }^{54}$ Pisarz planował opowiedzieć „historię dwóch żyjących w luksusie istot, żydowskich bliźniąt z przerafinowanego Berlina zachodniego [...]”. T. Mann, Noch einmal „Wälsungenblut"(list do Maurice'a Martina Du Garda, 21.08.1931), [w:] tegoż, Miszellen, hrsg. von Hans Bürgin, Frankfurt am Main-Hamburg 1968, s. 178. Pochodzenie Siegmunda i Sieglindy jest ściśle powiązane z dekadenckim rysem ich charakterystyki - to ludzie wybrani, byty wyjątkowe, odcinające się od wszelkiej pospolitości - a ten stanowi główny punkt odniesienia krytyki Manna i przedstawionej przez niego „odmowy asymilacji” społecznej. Zob. H.R. Vaget, Seelenzauber. Thomas Mann und die Musik, Frankfurt am Main 2012, s. 90. Cyt. za: J. Kühnel, dz. cyt., s. 144.

55 „Tym, co rzeczywiście mnie interesowało, była świadomość Sandry, jej moralna niewygoda, jej starania o to, by zrozumieć: chodzi tu o te same pobudki, które kierowały 'Ntonim, Livia, Rocco i księciem Saliną. I tak jak w innym miejscu posłużyłem się obrazami balu, bitwy, zjawiskiem emigracji wewnątrz Włoch, walką o chleb powszedni, tak tutaj zainspirowała mnie prastara zagadka Etrusków, Volterra, w której uzyskała ona tak doskonały wyraz, kompleks wyższości rasy żydowskiej, postać kobiety. To są elementy „historyczne”, fundamentalne i do 
skiego rodzeństwa jest jednak znaczący i zdaje się służyć czemuś więcej niż uwspółcześnieniu tematu zaczerpniętego z greckiej dramaturgii. Jeśli scena spotkania $\mathrm{w}$ etruskiej cysternie była polemika z romantycznym mitem zakochanego rodzeństwa, to sięgająca do Manna scena przy kominku jest kolejnym krokiem na drodze deromantyzacji historii rodzeństwa. Sądzę, że należy ją czytać łącznie z czwartą - i ostatnią - scena „,spotkania” Sandry i Gianniego na osobności oraz w świetle pewnej wypowiedzi Viscontiego, zanotowanej przez Liettę Tornabuoni.

Trójogniwowa seria intymnych tête-à-tête brata i siostry dopełnia się w domniemanej scenie niedoszłego gwałtu na Sandrze, której punkt kulminacyjny - rozgrywajacy się najprawdopodobniej, jak u Manna, na podłodze - Visconti pozostawia poza kadrem. Rękopis powieści Gianniego płonie w ogniu tego samego kominka, który palił się w salonie matki podczas wspólnego wskrzeszania wspomnień. Po patetycznym odejściu Andrew, przerażonego biegiem wypadków, Gianni - niczym nawykły „wyszydzać niezręczność namiętności” 56 bohater Manna - cynicznie ironizuje: „Wspaniałe wyjście! Schodzimy ze sceny. "Przedstawienie skończone»” („Magnifica uscita! Esce di scena. "La commedia è finita»"). Trudno w przypadku tak szczególnie wyczulonego na kwestie teatralizacji reżysera, jakim był Visconti, tego typu sformułowania uznać za neutralne, ale też trudno forsować znaczenie frazy niemającej oparcia w niczym innym poza nią samą. Czy miała ona odsyłać do Mannowskiego pomysłu teatralizacji incestu, użytego do krytyki postawy dekadenckiej? Warto zauważyć, że - tak jak w filmie Zmysły - naganę za teatralność włożył Visconti w usta swej najbardziej teatralnie postępującej postaci. Gianni romantyk w ostatniej tercji filmu ustępuje miejsca Gianniemu dekadentowi, który - zinfantylizowany i nieobliczalny - ratuje się złamanym romantycznym gestem: krzycząc w chwili śmierci, że nie chce umierać. Jeżeli za sprawą bohaterów, którzy „W swym wybujale prześmiewczym patosie samotności biorą sobie za wzór pra-incest Wagnerowskiego rodzeństwa Wälsungów" Thomas Mann chciał napiętnować postawę dekadenckiego przerafinowania, wykarmioną złym oddziaływaniem sztuki Wagnera ${ }^{57}$, przy okazji pokazując, jak łatwo Wagnerowski patos osuwa się w komizm, to Visconti - sięgając pół wieku później po oryginał i parodystyczną polemikę - pokazuje niejako drugą stronę tego

pewnego stopnia substancjalne, w których bierze początek akcja mojego filmu. Elementy psychologiczne to otwarte domaganie się sprawiedliwości i prawdy, emocjonalne i seksualne niezadowolenie Sandry oraz jej kryzys małżeński. Wreszcie istotny element stanowi dramat rodzinny (wspólny także postaciom z filmów, które wcześniej przywołałem)". L. Visconti, Un dramma del non essere..., s. 32-33.

${ }^{56}$ T. Mann, dz. cyt., s. 276.

${ }^{57}$ Zob. E. Koppen, dz. cyt., s. 153. 
samego problemu, którego mimochodem dotyka Mann, a który nazwać by można najtrzeźwiej niescenicznością Wagnera. Visconti mierzy sztukę mistrza z Bayreuth nie miara (szkodliwości) oddziaływania społecznego, a jedynie miarą doskonałości wyrazu artystycznego, toteż obraz połączenia Siegmunda i Sieglindy traktuje jako wzorzec miłości namiętnej. Wydaje się, że w tym punkcie wyczerpuje się sens trawestującego sięgnięcia po Manna i jego połączonych więzami krwi bohaterów. Ułatwiło ono trzy rzeczy: (1) spięcie materii współczesnej z mitem Elektry i Orestesa poprzez wprowadzenie wątku żydowskiego, (2) zdecydowane odromantycznienie uczucia Gianniego do Sandry przez nadanie bohaterowi w ostatnim spotkaniu z siostrą cech Siegmunda Aarenholda, (3) ukryta polemikę z komicznym odkształcaniem Wagnerowskiego patosu miłosnego. Wyraźnie widać, że Visconti sięga po elementy romantycznego sztafażu po to przede wszystkim, by - przez wzgląd na prawdę uczuć - rozgrzeszyć swego męskiego bohatera z pasji obcej „trywialnym egzystencjom”s8. Incest jawił mu się jako jedyne współczesne wcielenie miłości niemożliwej i w tym sensie ponawiał problem miłości romantycznej:

Chcę powiedzieć nie to, że incest jest w obyczajach naszego społeczeństwa sprawa powszechna - rzecz dotyczy czego innego. To problem zawodowy, narracyjny. Miłość szczęśliwa, spełniona, nie nadaje się na historię. Z pozytywnymi uczuciami nic się nie łączy, nauczyłem się tego na własnej skórze. Otóż w społeczeństwie takim, jak nasze nie istnieją już miłości niemożliwe, cudzołóstwo stało się lokalna pospolitościa, zakochiwanie się w Lolitach odruchem trawionego niepokojem pięćdziesięciolatka, nienormalność norma, nawet ménage à trois albo à quatre nie jest już aż taką rzadkością. Jedyną miłością niemożliwa, przeklęta, dramatyczną pozostaje incest - dlatego o nim opowiadam. Tak jak wcześniej opowiadano o Tristanie i Izoldzie, Paolu i Francesce czy choćby Madame Bovary ${ }^{59}$.

${ }^{58}$ Nawiązuję tu do zakończenia noweli Manna - wymiany zdań między rodzeństwem na temat znienawidzonego narzeczonego Sieglindy: „- Ale Beckerath, Gigi... co też z nim teraz będzie? - No, cóż - odparł i przez chwilę cechy jego rodu wystapiły mu nader ostro na twarzy - powinien nam być wdzięczny. Będzie wiódł odtąd znacznie mniej trywialną egzystencję" (T. Mann, dz. cyt., s. 297). Obszernie komentowano zmianę dokonaną przez pisarza w tej końcowej replice, w której pierwotnie występowały słowa w języku jidysz („Nun, was wird mit ihm sein? Beganeft haben wir ihn - den Goy") - jedyny w utworze element bezpośrednio przywołujący kontekst żydowski i skłaniający do interpretowania aktu incestualnego jako zemsty rodowej. Czasownik 'beganeft' znaczy 'oszukać'. Zob. James Northcote-Bade, Die Wagner-Mythen im Frühwerk Thomas Manns, Bonn 1975, s. 66-67.

59 „Non voglio dire che l'incesto sia un diffuso fenomeno nel costume della nostra società, la questione è un'altra. È un problema professionale, narrativo. L'amore felice, realizzato, non fa storia. Con i buoni sentimenti non si combina niente, l'ho imparato a mie spese. Ora in una società come la nostra gli amori impossibili non esistono più, l'adulterio è diventato volgarità paesana, innamorarsi di Lolita un tic da cinquantenne smanioso, l'anormalità una norma, persino i ménages a tre o a quattro non sono poi tanto rari. L'unico è quind il solo 


\section{Filozofia fabuły}

Na zakończenie wyliczmy jeszcze wybiórczo kilka rozwiązań pełniących funkcję wzmocnień dla wskazanej już linii fabularnej incestu:

(1) Sceny spotkań Sandry i Gianniego w ogrodzie i w etruskiej cysternie - wzmiankowane bez wyjątku we wszystkich dłuższych tekstach krytycznych poświęconych filmowi - zapadają w pamięć swą wyrazistością wizualna. Oddziałuja na podobieństwo obrazów malarskich i tak też są zbudowane, choć ich wybijająca się z przebiegu fabularnego statyka ma najwyraźniej jeszcze jednego patrona: operę i właściwa jej poetykę numerowa. Przynajmniej w tych dwóch momentach Visconti zdaje się przy pomocy „kontemplacyjnych duetów” ${ }^{60}$ odgrywanych w detalicznie zakomponowanych dekoracjach projektować w Btędnych gwiazdach Wielkiej Niedźwiedzicy coś w rodzaju dramaturgii stacyjnej. Taki gigantyczny wizualny naddatek właśnie i tylko w scenach duetów trzeba uznać za wybór znaczący, zarezerwowany dla treści o szczególnej doniosłości. Jeśliby posłużyć się retorycznym rozróżnieniem na poziom inwencji i elokucji, w uchwytnym tu „nadmiarowym” sposobie obrazowania - a więc na poziomie artykulacji artystycznej, narracji - dostrzeżemy wyraz tego, co wspiera fabułę w jej dążeniach, „współpracując w konstruowaniu sfery ideowej dzieła" ${ }^{61}$.

(2) Oprócz wskazanych już nawiązań do noweli Thomasa Manna $Z$ rodu Wälsungów na uwagę zasługuje jedna jeszcze, pomniejsza, analogia: scena toalety Siegmunda Aarenholda i scena toalety Gianniego (00:25:30 00:29:21) - pierwszy wyraźny sygnał tego, że zdenerwowanie Sandry ma coś wspólnego z cielesnościa.

(3) Motyw ślubny manifestuje się w sposób szczególny - choć nienachalny - w scenie w magistracie, przedstawiającej oczekiwanie na spóźniajacca się Sandrę na tle przygotowań do ceremonii zawarcia związku małżeńskiego: podczas podpisywania dokumentów donacyjnych brat i siostra zajmuja krzesła, na których za chwilę zasiądą (sugestywnie utrzymywani przez Viscontiego w głębi kadru) nowożeńcy.

amore impossibile, maledetto, drammatico: per questo l'ho raccontato. Se fossi vissuto prima avrei raccontato Tristano e Isotta, Paolo e Francesca, o magari Madame Bovary". L. Tornabuoni, Ai confini dell'amore, „L'Europeo”, 12.09.1965, s. 58-60. Cyt. za: M. Giori, dz. cyt., s. 88.

${ }^{60}$ Nawiązuję tu do znanego studium Carla Dahlhausa na temat „kontemplacyjnego ansamblu” operowego: C. Dahlhaus, Über das „kontemplative Ensemble”, [w:] tegoż, Vom Musikdrama zur Literaturoper. Aufsätze zu neueren Operngeschichte, München-Salzburg 1983, s. 33-38.

${ }^{61}$ Por. S. Wysłouch, Retoryka fabuty a retoryka narracji, [w:] Tekst i fabuła, red. Cz. Niedzielski, J. Sławiński, Wrocław 1979, s. 67-91. 
Mówiliśmy o tym, że fabuła filmu Viscontiego - o ile termin ten traktujemy jako nadrzędny w stosunku do akcji i obejmujemy nim „ogół w danym utworze przedstawionych (a w szczególności wyrażonych) zdarzeń i procesów, a więc wszystko to, co się dzieje w świecie przedstawionym", wzięte dokładnie w takiej postaci, jaką narzuca utwór ${ }^{62}$ - bliższa jest fabule zagadki aniżeli zwartej, „linearnie kulminującej”63 fabule kryminału. Przypomnijmy: zagadka w sposób omowny naprowadza słuchającego na właściwe rozwiązanie, posługując się określeniami tyleż przybliżającymi do przedmiotu, ile pozostawiającymi go w oddaleniu, odsłaniając przy tym swoistość samego kodu, w którym formułuje zapytanie. Częścią strategii narracyjnej Viscontiego - zderzającego na poziomie sensus literalis temat kazirodztwa z tematem Elektry - jest posługiwanie się w funkcji omowni wskazówkami literackimi, których odszyfrowanie pozwala uznać incest nie tylko za temat równorzędny mitycznemu, lecz także za temat właściwy. $\mathrm{Na}$ poziomie fabularnym Visconti pyta o to, jaka jest natura relacji łączącej Sandrę i Gianniego - tak jak w zagadkach pyta się o to, co to jest dzień i noc, gwóźdź w bucie czy kamień ${ }^{64}$. Nie daje wszakże jednoznacznej odpowiedzi, a ponadto wynosi swoje pytanie pułap wyżej: na poziomie filozoficznym a wiemy, że zagadkom pewnego typu bliżej do pytań tej natury aniżeli do błahych zabaw z gatunku „co mam na myśli” ${ }^{55}$ - pytanie mogłoby brzmieć nawet tak, jak jedna ze zgadywanek wpisanych w hymny Atharwawedy: „Czemuż nigdy, dążąc ku prawdzie, nie zatrzymują się wody?"66

\section{BIBLIOGRAFIA}

Abramowska J., Serie tematyczne, [w:] tejże, Powtórzenia i wybory. Studia z tematologii i poetyki historycznej, Poznań 1995, s. 34-52.

Ajschylos, Oresteja. Trylogia tragiczna, [w:] tegoż, Tragedie, przeł. i oprac. S. Srebrny, Warszawa 1954, s. 287-493.

Aprà A., et al., Intervista con Luchino Visconti, „Filmcritica” 1965, nr 159-160, s. 440. Aristarco G., Gli spiriti e le vaghe stelle, „Cinema Nuovo” 1965, nr 178, s. 441-443.

${ }^{62}$ R. Ingarden, Studia z estetyki, Warszawa 1966, t. 2, s. 393.

${ }^{63}$ W.J. Ong, Oralność i piśmienność. Stowo poddane technologii, przeł. i oprac. J. Japola, Warszawa $2011^{2}$, s. 212-224.

${ }^{64}$ Por. L. Witkowski, Przekaz antyku w polskiej zagadce literackiej i ludowej, Toruń 1971, s. 48-206. Przywołajmy tu poglądowo tylko tę pierwszą w polskiej wersji z XIX wieku: „Jest nas dwie Siostry sobie rodzone/ Ona mnie rodzi, ia wzaiem onę./ Jesteśmy siostry i sobie Matki,/ Ktoż nam rozwiąże, nasze zagadki" (tamże, s. 116).

${ }^{65}$ Zob. J. Huizinga, Homo ludens. Zabawa jako źródto kultury, przeł. M. Kurecka, W. Wirpsza, Warszawa 1998, s. 181-201.

${ }^{66}$ Atharwaweda X, 7, 37. Cyt. za: J. Huizinga, dz. cyt., s. 185. 
D’Annunzio G., Może tak, może nie (Forse che si, forse che no), przeł. H. Żółkiewska, Warszawa 1912.

Dahlhaus C., Über das „,kontemplative Ensemble”, [w:] tegoż, Vom Musikdrama zur Literaturoper. Aufsätze zu neueren Operngeschichte, München-Salzburg 1983, s. 33-38.

Eurypides, Elektra, przeł. i oprac. S. Łanowski, Wrocław 1969.

Frenzel E., Orests Rache [hasło], [w:] tejże, Stoffe der Weltliteratur. Ein Lexikon dichtungsgeschichtlicher Längsschnitte, Stuttgart $2005^{10}$, s. 697-702.

Giori M., Scandalo e banalità. Rappresentazioni dell'eros in Luchino Visconti (19631976), Milano 2012, s. 85-122.

Głowiński M., O intertekstualności, [w:] tegoż, Poetyka i okolice, Warszawa 1992, s. 87-124.

Helman A., Urok zmierzchu. Filmy Luchina Viscontiego, Gdańsk 2001, s. 191-209.

Huizinga J., Homo ludens. Zabawa jako źródło kultury, przeł. M. Kurecka, W. Wirpsza, Warszawa 1998, s. 181-201.

Ingarden R., Studia z estetyki, Warszawa 1966, t. $2^{2}$, s. 355-494.

Koppen E., Dekadenter Wagnerismus. Studien zur europäischen Literatur des Fin de siècle, Berlin-New York 1973, s. 93-164.

Kühnel J., „Braut und Schwester bist du dem Bruder”. Der Geschwisterinzest in der „Völsunga saga", bei Richard Wagner und Thomas Mann, [w:] Les Interdits. Actes du Colloque international des 1 ${ }^{\text {er }}, 2$ et 3 Mars 2012 à Amiens, Amiens 2012, s. 134-148.

Mann T., Noch einmal „Wälsungenblut”, [w:] tegoż, Miszellen, hrsg. von H. Bürgin, Frankfurt am Main-Hamburg 1968, s. 176-179.

Mann T., Z rodu Wälsungów, przeł. M. Kurecka, [w:] tegoż, Opowiadania, przeł. M. Kurecka et al., Warszawa 1963, s. 268-297.

Micciché L., Luchino Visconti. Un profilo critico, Venezia $2002^{2}$.

Northcote-Bade J., Die Wagner-Mythen im Frühwerk Thomas Manns, Bonn 1975, s. 53-67.

Ong W.J., Oralność i piśmienność. Stowo poddane technologii, przeł. i oprac. J. Japola, Warszawa $2011^{2}$, s. 212-224.

Osma G. de, Mariano Fortuny. His life and work, trans. by S. Berg, London 2015.

Parigi S., Vaghe stelle dell'Orsa... Il deposito della memoria, [w:] Il Cinema di Luchino Visconti, a cura di V. Pravadelli, Venezia 2002, s. 221-234.

Piwińska M., Kochana siostra, w: tejże, Złe wychowanie. Fragmenty romantycznej biografii, Warszawa 1981, s. 292-312.

Rondolino G., Visconti e il nuovo cinema degli anni sessanta, [w:] Visconti. Il cinema, a cura di A. Ferrero, Modena 1977, s. 129-141.

Rusconi M., Il Leone d'oro al magnetofono, „Sipario” 1965, nr 234, s. 11-13.

s. n., „Vaghe stelle dell'Orsa nell'itinerario di Visconti, „Cinema Nuovo” 1966, nr 180, s. $106-116$.

Sofokles, Elektra, przeł., wstępem i przypisami opatrzył R.R. Chodkowski, Lublin 2008. Tornabuoni L., Ai confini dell'amore, „L'Europeo”, 12.09.1965, s. 58-60.

Vaget H.R., Seelenzauber. Thomas Mann und die Musik, Frankfurt am Main 2012, s. 78-96.

Vaghe stelle dell'Orsa... di Luchino Visconti, a cura di P. Bianchi, Bologna 1965.

Visconti a Volterra. La genesi di „Vaghe stelle dell'Orsa”, a cura di V. Pravadelli, Torino 2000. 
Visconti L., Ein Drama über das Nicht-Sein, übers. von M. Schneider, [w:] Visconti. Schriften, Filme, Stars und Stills, hrsg. von M. Schneider u. L. Schirmer, München 2008, s. 55-57.

Wagner N., Wagner Theater, Frankfurt am Main-Leipzig 1998, s. 89-107.

Wagner R., Walkiria, przeł. M. Łukasiewicz, Warszawa 1988.

Witkowski L., Przekaz antyku w polskiej zagadce literackiej i ludowej, Torun 1971.

Wysłouch S., Retoryka fabuły a retoryka narracji, [w:] Tekst i fabuła, red. Cz. Niedzielski, J. Sławiński, Wrocław 1979, s. 67-91. 
